\title{
Metallothionein from Wild Populations of the African Catfish Clarias gariepinus: From Sequence, Protein Expression and Metal Binding Properties to Transcriptional Biomarker of Metal Pollution
}

\author{
Ethel M'kandawire 1,2, Agnieszka Mierek-Adamska ${ }^{1,3}$, Stephen R. Stürzenbaum ${ }^{4}$, \\ Kennedy Choongo ${ }^{2}$, John Yabe ${ }^{2}$, Maxwell Mwase ${ }^{2}$, Ngonda Saasa ${ }^{2}$ and Claudia A. Blindauer ${ }^{1, *}$ \\ 1 Department of Chemistry, University of Warwick, Coventry CV4 7AL, UK; \\ ethel.mkandawire@unza.zm (E.M.); mierek_adamska@umk.pl (A.M.-A.) \\ 2 School of Veterinary Medicine, University of Zambia, P.O. Box 32379, Lusaka 10101, Zambia; \\ k.choongo@unza.zm (K.C.); mjyabe@yahoo.co.uk (J.Y.); mmwase@yahoo.com (M.M.); \\ nsaasa@gmail.com (N.S.) \\ 3 Department of Genetics, Faculty of Biology and Environmental Protection, Nicolaus Copernicus University, \\ 87-100 Torun, Poland \\ 4 Analytical and Environmental Sciences Division, Faculty of Life Sciences \& Medicine, King's College \\ London, London SE1 9NH, UK; stephen.sturzenbaum@kcl.ac.uk \\ * Correspondence: c.blindauer@warwick.ac.uk; Tel.: +44-24-765-28264
}

Received: 2 May 2017; Accepted: 13 July 2017; Published: 18 July 2017

\begin{abstract}
Anthropogenic pollution with heavy metals is an on-going concern throughout the world, and methods to monitor release and impact of heavy metals are of high importance. With a view to probe its suitability as molecular biomarker of metal pollution, this study has determined a coding sequence for metallothionein of the African sharptooth catfish Clarias gariepinus. The gene product was recombinantly expressed in Escherichia coli in presence of $\mathrm{Zn}(\mathrm{II}), \mathrm{Cd}(\mathrm{II})$, or $\mathrm{Cu}$, and characterised by Electrospray Ionisation Mass Spectrometry and elemental analysis. C. gariepinus MT displays typical features of fish MTs, including 20 conserved cysteines, and seven bound divalent cations (Zn(II) or Cd(II)) when saturated. Livers from wild C. gariepinus fish collected in all three seasons from four different sites on the Kafue River of Zambia were analysed for their metal contents and for MT expression levels by quantitative PCR. Significant correlations were found between $\mathrm{Zn}$ and $\mathrm{Cu}$ levels and MT expression in livers, with MT expression clearly highest at the most polluted site, Chililabombwe, which is situated in the Copperbelt region. Based on our findings, hepatic expression of MT from C. gariepinus may be further developed as a major molecular biomarker of heavy metal pollution resulting from mining activities in this region.
\end{abstract}

Keywords: Kafue River; heavy metals; Clarias gariepinus; liver; metallothionein; MT gene expression; biomarker; toxicogenomics

\section{Introduction}

Heavy metal contamination of fresh water systems is of serious concern worldwide because metals have the ability to bioaccumulate in aquatic organisms, and, in contrast to organic pollutants, are non-degradable [1-3]. Some metals such as $\mathrm{Fe}, \mathrm{Cu}, \mathrm{Co}, \mathrm{Mn}$ and $\mathrm{Zn}$ are essential to biological life forms, but become toxic above their threshold concentrations [4,5]. Other metals including As, Cd, $\mathrm{Hg}$ and $\mathrm{Pb}$ are non-essential and may be toxic even at minute concentrations [6]. Heavy metals enter aquatic systems by either natural or anthropogenic sources [6]. Metals released into aquatic bodies may be dissolved or suspended in water, deposited in sediments, or assimilated in aquatic biota [7]. In fish, 
heavy metals may cause physiological, biochemical, morphological and haematological changes as well as oxidative stress [8]. Because fish is a major component of the human diet in many parts of the world, bioaccumulation of heavy metals in commercial edible fish may pose health risks to fish consumers [9]. Acute heavy metal toxicity in man causes amongst other symptoms tremor, ataxia, paralysis, convulsions, haemoglobinuria, and gastrointestinal disorders such as diarrhoea, vomiting and stomatitis $[6,10]$. Chronic exposure may lead to neurotoxic, carcinogenic, mutagenic or teratogenic effects [10]. A prominent example of river water-derived heavy metal poisoning is that of Itai-Itai (Ouch-Ouch) disease, a combination of osteomalacia, osteoporosis and pain in bones, which was discovered in the 1950s and was caused by cadmium contamination of the Jinzu River [11].

In Zambia, the Kafue River has been receiving effluents from industrial, agricultural, mining and domestic/sewage wastes over a long period of time, leading to the deterioration of the river's ecosystems. In particular, mining waste from the Copperbelt mining area has been implicated in environmental degradation of Kafue River ecosystems [12,13]. To begin to mitigate the effects of mining activities, heavy metal concentrations in the Kafue River have been measured in water [14], sediments $[15,16]$ and biota $[16,17]$. However, studies on monitoring the extent and effects of metal pollution in the river through biomarker studies are extremely scarce [14]. A biomarker is defined as any biological response measured inside an organism at molecular, biochemical or cellular level or in an organism's products (urine, faeces, feathers and others) indicating a departure from the normal status as a result of exposure to potentially toxic chemicals [18]. The most compelling reason for using biomarkers is that they can give information on the biological effects of pollutants rather than a mere quantification of their environmental levels. In the case of heavy metals, biomarker monitoring involves the assessment of exposure and effects of heavy metals in organisms by determining early adverse alterations that may be partly or fully reversible, and by examining the occurrence of irreversible diseases or tissue damage in organisms [1,3].

The potential of metallothioneins (MTs) to be used to measure an organism's exposure and response to toxic levels of metal ions was recognised soon after their discovery [19]. Meanwhile, MTs have been proposed for or already have been used in biomonitoring programmes to characterise metal contamination in aquatic environment [20-28]. MTs occur in virtually all eukaryotes and some bacteria [29]. They constitute a super-family of soluble, cysteine-rich, low molecular weight (usually $<10 \mathrm{kDa}$ ) proteins with high affinity and capacity to bind thiophilic metal ions (in particular $\mathrm{Zn}$ (II), $\mathrm{Cu}$ (I), $\mathrm{Cd}(\mathrm{II}), \mathrm{Hg}(\mathrm{II})$ and $\mathrm{Ag}(\mathrm{I}))$ in characteristic metal-thiolate clusters [29-33]. The MT super-family is unusual in that it is polyphyletic, i.e., its members are thought to originate not from a common ancestor, but to be examples of convergent evolution [34]. Thus, since this super-family is defined mainly through chemical properties rather than structure and function, its members have several different biological functions, and the main function may differ depending on organism and tissue [35]. In vertebrates including fish, the primary function of MTs concerns homeostasis of essential metals such as $\mathrm{Cu}$ and $\mathrm{Zn}$, keeping these metal ions safe but potentially available within the intracellular environment $[35,36]$. In addition, their high thiol content renders MTs redox-active [37] and able to respond to oxidative stress [35,38]. Finally, owing to their inducibility by a range of heavy metals [30] and enhanced tolerance towards acute administration of these [39,40], their role in detoxifying non-essential, toxic metals is widely cited. Exposure to excessive levels of essential metals (e.g., $\mathrm{Zn}$ and $\mathrm{Cu}$ ) or toxic metals (e.g., $\mathrm{Cd}, \mathrm{Hg}, \mathrm{Ni}, \mathrm{Ag}, \mathrm{Au}, \mathrm{Pb}$, $\mathrm{As}$, and $\mathrm{Bi}$ ) leads to at least temporary increases of these metals in the cytosol and nuclei of cells [41]. One response of the cell to this situation consists in the upregulation of MT gene transcription [30]; this is at least in part mediated through the action of metal-responsive elements (MREs) found in the promoter regions of MT genes [42], including those of fish [43,44]. Like those of mammals [45], fish MT gene promoter regions also contain response elements for oxidative stress (antioxidant response elements (AREs) and activator protein-1 (AP-1) binding sites), glucocorticoids (GREs) and cytokines [46,47]; thus, heavy metals are not the only factors affecting MT transcription. Furthermore, the actual molecular mechanisms for MT induction by xenobiotic heavy metals are still not entirely clear; an initial hypothesis involving Zn(II) displacement from basal MT by the incoming metal, followed by activation of the MRE-binding zinc sensor MTF-1 is not entirely consistent with experimental evidence [48,49]. 
Irrespective of unclear mechanistic details, increased expression of MTs in response to harmful levels of metals has been demonstrated in fish $[3,26,44,50]$. The capacity for MT induction is greatest in tissues that are active in uptake, storage and excretion, such as the small intestine, liver and gills [2,20,26,51]. Although not all fish species respond to heavy metal exposure by MT induction [52], numerous studies have concluded that MTs are sensitive and efficient biomarkers for evaluating the cumulative biological effects of metal exposure in fish [3,26-28]. MT induction can in principle be measured either at protein [51,53-55] or mRNA level. Quantifying protein, especially when combined with chromatography and elemental analysis, allows determination of which metal ions the MT is associated with [56,57]. However, for biomarker studies, mRNA may not only be easier to measure, but also more reliable, as mRNA does not necessarily become translated, and/or protein levels do not always reflect the degree of exposure $[23,58]$. An extreme case concerns a hemoglobinless ice fish, in which massive increases in hepatic mRNA were accompanied by undetectable MT protein [59]. For these reasons, mRNA quantitation may provide a more sensitive measure of heavy-metal exposure.

Several laboratory studies $[24,60]$, as well as a number of field studies in natural fish populations $[23,55,61]$ around the globe have successfully employed fish MT mRNA quantification as a biomarker of heavy metal stress (also see $[3,26]$ and references therein). However, although a number of studies have investigated heavy metal accumulation in sediments and fish in Zambia [16,62], MT expression in Kafue River fish, and any correlation with pollution-related heavy metal bioaccumulation has not been explored so far.

Previously, one of the authors of the present study has demonstrated a positive correlation between MT expression and liver metal contents in the antelope Kafue lechwe (Kobus leche kafuensis) [63]. For the present study, the African sharptooth catfish (Clarias gariepinus) was selected as model species. C. gariepinus is found in unpolluted and polluted aquatic environments throughout many African and Asian countries. It grows at a fast rate and can live up to eight years, and thus has potential to accumulate high levels of heavy metals. Catfish are also omnivorous [64] and bottom feeders (benthic species) [65], and are thus readily exposed to metals that accumulate in river sediments. Hence, they are particularly useful as bio-indicators of aquatic pollution. Moreover, C. gariepinus is a popular delicacy relished throughout tropical Africa and if heavily contaminated, may pose health risks to its consumers [66]. Metal bioaccumulation and biomarkers of heavy metal pollution have been studied previously in C. gariepinus $[64,67,68]$.

Metal-induced MT induction in liver, as the main detoxification organ, is well-documented, including in fish in laboratory culture $[60,69,70]$ and in field studies involving feral fish [71-74]. Therefore, the current study determined heavy metal concentrations and MT expression levels in C. gariepinus livers at four sites along the Kafue River over three seasons. Since the genome of $C$. gariepinus has not yet been sequenced, cDNAs were amplified from MT mRNAs by reverse transcription polymerase chain reaction (RT-PCR) [75], and the sequences were determined. To check whether the cloned cDNA encodes functional protein, we also cloned the putative coding sequence into E. coli for overexpression. This allowed studies on metal binding properties of $C$. gariepinus MT protein. We found that $C$. gariepinus possesses at least one MT gene and that the translated protein sequence displays all typical hallmarks of fish MTs [36]. Like all other vertebrate MTs, the expressed protein bound seven molar equivalents of $\mathrm{Zn}$ (II) or Cd(II), whilst repeated attempts to isolate Cu-bound MT failed. Nonetheless, MT expression in 155 fish livers correlated most strongly with liver contents of $\mathrm{Cu}$, besides those for Zn. We conclude that MT expression in C. gariepinus responds to elevated pollution with $\mathrm{Cu}$ resulting from mining activities in the Copperbelt region, and that MT expression may serve as a suitable biomarker of such pollution.

\section{Results and Discussion}

To evaluate hepatic MT as a biomarker of heavy metal pollution in C. gariepinus from the Kafue River, a cross-sectional study involving three time points and several study sites was conducted. 


\subsection{Study Area and Sampling Regime}

The Kafue River is about $1600 \mathrm{~km}$ long; it originates in the North Western Province of Zambia and flows through four provinces, namely Copperbelt, Central, Southern and Lusaka provinces, before its confluence with the Zambezi River [76]. Over ten endemic species of fish including C. gariepinus are found in its waters [77]. Communities rely on these fish stocks for income and over $70 \%$ of their daily protein intake [78]. For our cross-sectional study, we initially selected six sites (Figure 1) along the Kafue River, namely Chimfunshi (non-industrialised area, upstream of the Copperbelt mining and industrial area, reference site), Chililabombwe, Chingola-Kanyemo and Chingola-Hippo Pool (all three sites within the Copperbelt mining and industrial area), Kafue Flats and Kafue Town (downstream of the Copperbelt mining and industrial area). The sites were purposively selected based on their proximity to the Copperbelt mining area, accessibility and presence of fishing camps. Fish and sediment samples were collected during 2014 for each of three seasons: warm-rainy (April), dry-cold (June) and dry-hot (September) season.

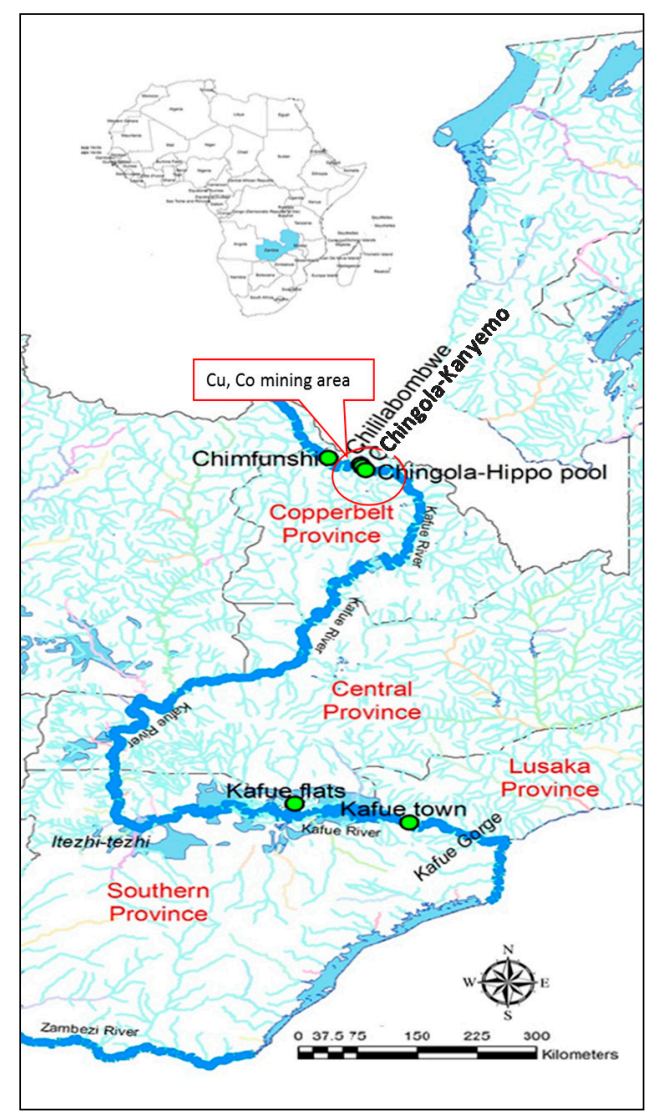

Figure 1. Map of Zambia showing the location of the Copperbelt mining area and sampling sites along the Kafue River.

C. gariepinus fish were only obtained from Chimfunshi, Chililabombwe, Kafue Flats and Kafue Town; no fish were caught at Chingola-Kanyemo and Chingola-Hippo Pool in any season, probably because of high levels of heavy metal pollution resulting from mining waste discharge at these sites. Although factors relating to fishing patterns could have contributed to lack of fish, mining activities can reduce biodiversity and alter species composition in aquatic bodies [79]. Indeed, the disappearance of hippopotami (Hippopotamus amphibius) from the Kafue River in Chingola has been attributed to heavy metal accumulation from the Copperbelt mining area [80]. Our previous results on heavy metal levels in sediments of the Kafue River showed that the two Chingola sites were highly polluted 
throughout the year [81], although it is noteworthy that this was also true of Chililabombwe. The latter site is the most upstream of the three sites.

\subsection{Identification of C. gariepinus Metallothionein cDNA Sequence}

The most essential prerequisite for biochemical biomarker studies, irrespective of whether these are based on the quantitation of mRNA or protein, is sequence information on the prospective biomarker. In the absence of a sequenced genome for $C$. gariepinus, MT coding regions were amplified from mRNA extracted from eight different livers from C. gariepinus collected at the four different sites. This required the design of degenerate primers; these were based on gene sequences of MTs from closely related fish species retrieved from GenBank (see Materials and Methods for details). PCR using these primers led to the clean production of PCR products of the expected size (Figure S1). Sequencing of these products followed by in silico analysis of the results revealed in each case the presence of a $183 \mathrm{bp}$ coding sequence (CDS). The translation products of these sequences are proteins that contain 20 cysteine residues out of 60 amino acids (Figure 2a). We observed some small variations in some non-cysteine residues; these are suggested to be due to single-nucleotide polymorphism (see Figure $\mathrm{S} 2$ for respective cDNA sequences and translation products). The cDNA sequence (cgMT hereafter, accession no. KU999947) found in the majority of the eight fish was selected for further studies. This is the first report on a complete CDS for C. gariepinus MT; a partial CDS had been previously deposited at NCBI (accession no. DQ885944.1); over the 102 common nucleotide residues, our cgMT sequence shows 100\% identity with DQ885944.1. Further BLASTN hits included the MTs from the closely related C. macrocephalus (AGC79139.1; 95\% identity), and from Poecilia reticulata (XM_008412689.1; 79\% identity). A BLASTP search with the predicted amino acid sequence of CgMT yielded also the MT from C. macrocephalus (AGC79139.1; 93\% identity) and the channel catfish Ictalurus punctatus (NP_001187006.1; 93\% identity).

(a)

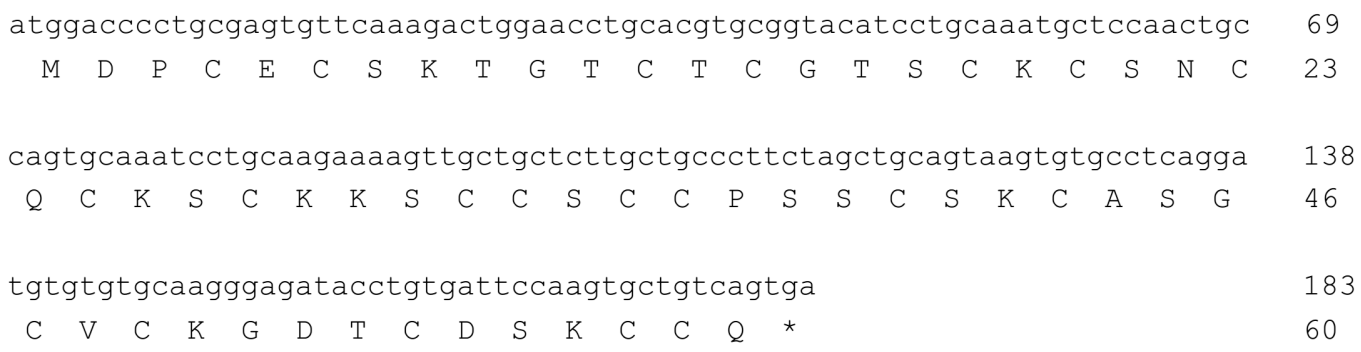

Figure 2. (a) Cloned cDNA sequence of $c g M T$ and predicted amino acid sequence of CgMT. At the end of each line, the position of the last nucleotide/amino acid is marked; (b) Sequence alignment of CgMT (row 1) with MTs from other catfish (rows 2-4), other fish (rows 5-8), and two mammalian MTs (rows 9 and 10). Cysteines and lysines are highlighted in yellow and cyan, respectively. 
The existence of MT-like proteins in fish has been recognised for some while [82]; there is now also a large body of work on the nucleotide level [36]. Some fish of the Salmoniformes family and Notothenoids have two MT genes [36] (also see Figure 2b for respective proteins), but most likely C. gariepinus only possesses a single MT gene, like Ictalurus punctatus, for which a sequenced genome is available [83]. The CgMT protein (Figure $2 \mathrm{~b}$ ) displays features typical of vertebrate MTs in general $[29,30,35]$, and fish MTs in particular [36,84]. Its predicted molecular weight (excluding metal ions) is $6138.16 \mathrm{Da}$, typically low as for the vast majority of MTs. Its sequence is 60 amino acids long, with 20 Cys residues arranged in $\mathrm{CC}, \mathrm{CxC}$, and $\mathrm{CxxC}$ motifs, it is devoid of histidine or other aromatic residues, and it has a high proportion of lysine residues, i.e., eight in total, the same number as in Notothenia coriiceps MTA (Figure 2b) or mammalian MT2s. (The lack of aromatic residues is a frequently cited feature of MTs, but we note that there are many exceptions to this rule: chicken MT and even some mammalian MTs do contain His residues, and in bacterial and some plant MTs, they participate crucially in metal binding [85].) The latter fact, together with the presence of only four carboxylate side-chains, is responsible for its relatively high theoretical isoelectric point of 8.23 , very close to those of other vertebrate including fish MTs [34,36,53]. In (mammalian) MTs, lysines are known to stabilise the metal-thiolate clusters [86], which are overall negatively charged ( -3 for $\mathrm{M}(\mathrm{II})_{3} \mathrm{Cys} 9$ and -1 for $\left.\mathrm{M}(\mathrm{II})_{4} \mathrm{Cys}_{11}\right)$. It may be worth noting here that precisely because of the presence of these charged metal-thiolate clusters, experimental isoelectric points differ considerably from the theoretical values, which do not take into account either metal ions or deprotonated cysteines.

Out of the 20 Cys residues in CgMT, 19 are in the same positions as those in non-fish vertebrate MTs. Only the 18th Cys is "shifted" from position 56 to position $54-$ a feature that is unique to fish MTs [36,87]. The solution structure of cadmium-loaded MTA from the icefish Notothenia coriiceps has been determined by ${ }^{1} \mathrm{H}$ and ${ }^{113} \mathrm{Cd}$ NMR spectroscopy [88]. Like other vertebrate MTs, the polypeptide chain folds into two largely independent globular domains, an $\mathrm{N}$-terminal $\beta$-domain containing an $\mathrm{M}(\mathrm{II})_{3} \mathrm{Cys}_{9}$ cluster, and a C-terminal $\alpha$-domain containing an $\mathrm{M}(\mathrm{II})_{4} \mathrm{Cys}_{11}$ cluster. The different location of a single Cys residue requires a change in the backbone conformation in the C-terminal region, and it has been suggested that this is a major determinant of the higher reactivity of fish MTs compared to mammalian MTs, when this is assessed under the exactly identical conditions. Another salient feature of fish MTs is their very high hydrophilicity [89]; this is also the case for CgMT, where its GRAVY (grand average of hydropathicity; the lower the GRAVY, the more hydrophilic the protein) value is -0.248 . For comparison, this value is -0.005 for rat MT2. The higher hydrophilicity of fish MTs mainly results from an increase in serine and threonine residues at the cost of alanine and valine residues, along with a shift from an isoleucine to a valine residue (see Figure $2 b$ ). The higher hydrophilicity is also thought to increase conformational flexibility. Together, the higher flexibility and reactivity for fish MTs is thought to be a requirement arising from the fact that these animals operate at lower body temperatures than, e.g., mammals or reptiles [89].

Given the very high sequence similarity of CgMT with structurally characterised fish and mammalian MTs (Figure 2b), it can be suggested that CgMT adopts the same fold as these, and has similar metal-binding properties. In particular, one would expect that fully metal-loaded CgMT would have $7 \mathrm{M}(\mathrm{II})(\mathrm{Zn}$ or $\mathrm{Cd}$ ) ions bound, and potential to bind up to $12 \mathrm{Cu}(\mathrm{I})$ ions in two clusters $[29,30,33,88]$. To establish that the isolated cDNA sequence indeed codes for a functional protein, and to verify these predictions, we have recombinantly expressed CgMT in E. coli. The expression of eukaryotic MTs in this bacterial host has been carried out for scores of MTs, and, in many cases, it has been possible to synthesise and purify metallated protein [90-93]. This approach may be safer than in-vitro reconstitutions of apo-proteins, especially when no affinity tags are used for purification.

\subsection{Expression and Metal-Binding Properties of Recombinant CgMT}

MT proteins from fish have been quantified extensively, but studies involving biophysical characterisation are relatively rare $[36,87,88,94,95]$. 
In order to be able to synthesise CgMT protein in quantities sufficient for characterisation, $\operatorname{cgMT}$ cDNA was cloned into a pET-based expression vector, without any tags or surplus residues. DNA sequencing of the pET-cgMT expression construct confirmed that it contained the coding sequence of $c g M T$ with no point mutations. The recombinant synthesis of CgMT was performed in the presence of zinc, cadmium, or copper. Whilst Zn(II)- and Cd(II)-bound CgMT were readily isolated from cell lysates in their metal-bound forms, we were repeatedly unable to recover sufficient protein from the copper-supplemented cultures using identical purification procedures.

After purification of the metallated proteins by size-exclusion and anion-exchange chromatography, the identity and integrity of the CgMT protein were confirmed by Electrospray-Ionisation Mass Spectrometry (ESI-MS), after acidification of the purified protein solutions to $\mathrm{pH}$ 2.2-2.3. Across all preparations, a neutral molecular mass of $6137.70 \pm 0.37 \mathrm{Da}$ was found, in good agreement with the theoretical neutral mass of 6138.16 Da for the full 60-residue polypeptide (Figure 3). As should be the case [96], the N-terminal methionine was not cleaved; this residue is typically also present in vertebrate MTs isolated from the native host. In addition, each spectrum revealed the presence of two additional species: (i) The apo form of CgMT where the N-terminal methionine was still formylated (the average difference between the masses of the apo form and the fMet apo form, measured in individual spectra, was $27.11 \mathrm{Da}$, close to the expected $28.01 \mathrm{Da}$ ). This is a common feature of proteins overexpressed in E. coli [97]; (ii) There was a minor peak for a CgMT species with one metal ion bound (Figure 3). The fMet peak also overlaps with the peak for a mono-sodium adduct $(+21.99 \mathrm{Da})$.

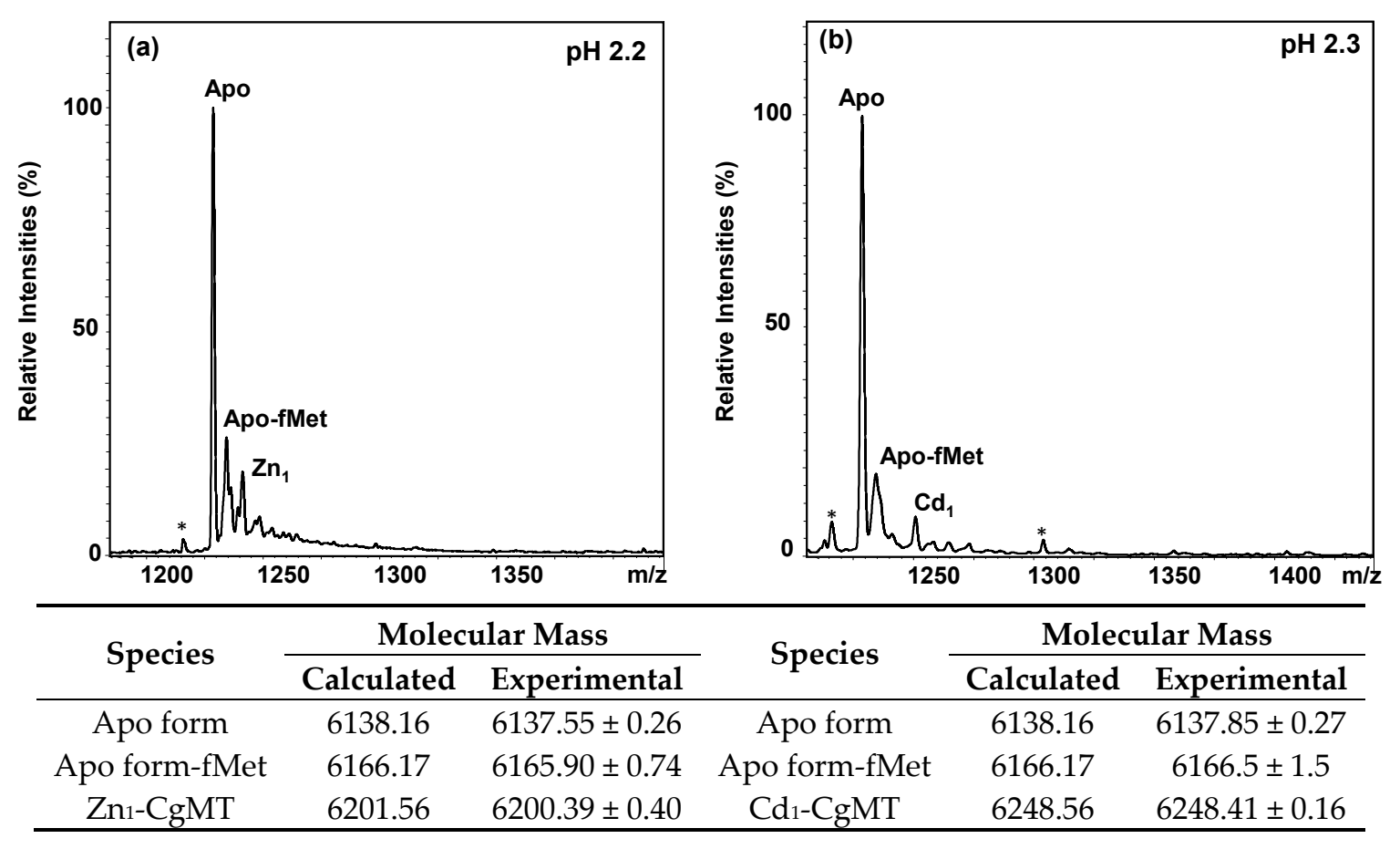

Figure 3. The most abundant +5 charge state from representative ESI-MS spectra of CgMT synthesised in the presence of: (a) $\mathrm{Zn}(\mathrm{II})$; or (b) $\mathrm{Cd}(\mathrm{II})$, recorded at acidic $\mathrm{pH}\left(10 \mathrm{mM} \mathrm{NH}_{4} \mathrm{HCO}_{3}, 10 \% \mathrm{MeOH}, 2 \%\right.$ formic acid). Peaks marked with an asterisk $\left(^{*}\right)$ indicate impurities.

Next, Inductively-Coupled Plasma Optical Emission Spectroscopy (ICP-OES) and ESI-MS were used to determine the metal-to-protein stoichiometry of metal-CgMT complexes. The ICP-OES results reported in Table 1 and the ESI-MS results reported in Figure 4 clearly demonstrate that for both $\mathrm{Zn}(\mathrm{II})$ and $\mathrm{Cd}(\mathrm{II})$ the expected [30,98] 7-M(II) species overwhelmingly dominate speciation at 
neutral $\mathrm{pH}$. Interestingly though, preparations in presence of $\mathrm{Cd}(\mathrm{II})$ also contained over- $(8 \mathrm{M}(\mathrm{II}))$ and under- $(6 \mathrm{M}(\mathrm{II}))$ metallated species, and some $\mathrm{Zn}(\mathrm{II})$ was also bound to the protein.

Table 1. Metal stoichiometry of recombinant CgMT protein expressed in presence of $\mathrm{Zn}$ (II) or Cd(II), as determined by elemental analysis (ICP-OES).

\begin{tabular}{cccccccc}
\hline $\begin{array}{c}\text { Supplemented } \\
\text { Ion }\end{array}$ & $\begin{array}{c}\text { Sulphur } \\
(\mathbf{m g} / \mathrm{L})\end{array}$ & $\begin{array}{c}\text { Sulphur } \\
(\boldsymbol{\mu M})\end{array}$ & $\begin{array}{c}\text { Protein } \\
(\boldsymbol{\mu M})\end{array}$ & Metal & $\begin{array}{c}\text { Metal } \\
(\mathbf{m g} / \mathbf{L})\end{array}$ & $\begin{array}{c}\text { Metal } \\
(\boldsymbol{\mu M})\end{array}$ & $\begin{array}{c}\text { M: Protein } \\
\text { Ratio }\end{array}$ \\
\hline $\mathrm{Zn}(\mathrm{II})$ & 0.78 & 97.81 & 4.66 & $\mathrm{Zn}$ & 0.54 & 33.06 & $6.88 \pm 0.89$ \\
$\mathrm{Cd}(\mathrm{II})$ & 2.31 & 144.38 & 6.88 & $\mathrm{Cd}$ & 2.98 & 53.01 & $7.72 \pm 0.83$ \\
\hline
\end{tabular}

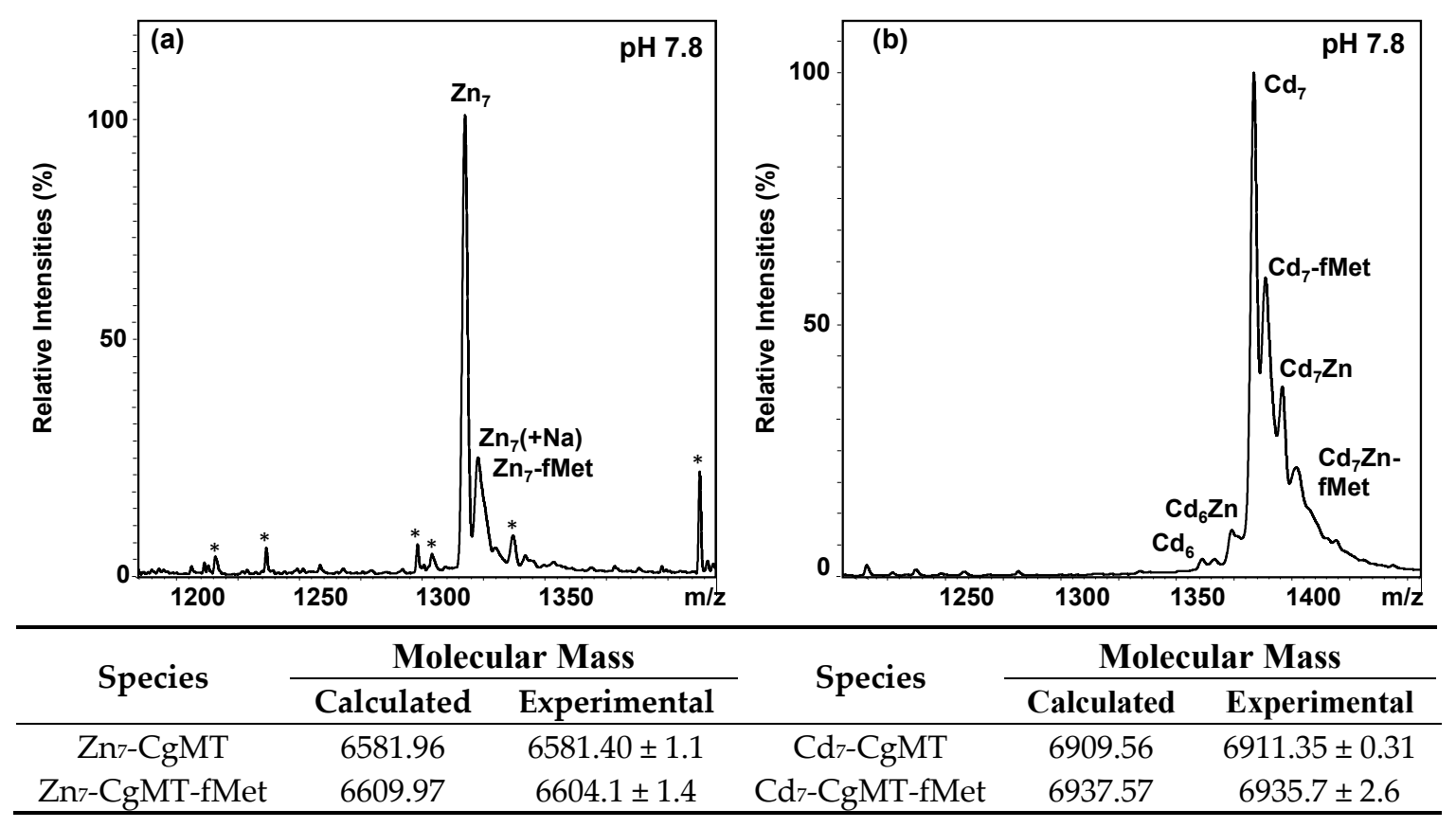

Figure 4. The most abundant +5 charge state of representative ESI-MS spectra of: (a) Zn(II)-CgMT; or (b) $\mathrm{Cd}(\mathrm{II})-\mathrm{CgMT}\left(10 \mathrm{mM} \mathrm{NH} \mathrm{HCO}_{3}, 10 \% \mathrm{MeOH}\right)$ at native $\mathrm{pH}$. The relatively large errors for the experimental masses for the fMet species are due to its low abundance and overlap with a sodium adduct that cannot be resolved for the metal-containing species due to their broad isotopic distributions. Peaks marked with an asterisk $\left.{ }^{*}\right)$ indicate impurities.

The fairly straightforward elemental analysis and mass spectrometry data, together with the high degree of conservation between CgMT and Notothenia coriiceps MTA (Figure 2) allowed generating a simple homology model for the $\mathrm{Cd}(\mathrm{II})_{7}-\mathrm{CgMT}$ species, depicted in Figure 5 . The image illustrates the typical two-domain structure of vertebrate (and many other animal and plant) MTs. Apart from a short stretch of $\alpha$-helix (residues Glu5-Thr9), no elements of regular secondary structure are present. The canonical $\mathrm{M}(\mathrm{II})_{3} \mathrm{Cys}_{9}$ and $\mathrm{M}(\mathrm{II})_{4} \mathrm{Cys}_{11}$ clusters determined for Notothenia MTA could be fitted effortlessly into the homology model.

In summary, the MT from C. gariepinus displays hallmarks of a typical Zn-MT [91]: with the divalent ions $\mathrm{Zn}(\mathrm{II})$ and $\mathrm{Cd}(\mathrm{II})$, it forms complexes with very well-defined stoichiometry, whilst in vivo in E. coli, copper could not stabilise the protein sufficiently to enable isolation of purified protein. In contrast, metal speciation studies on MTs isolated from, e.g., carp liver have indicated the existence of copper-bound MTs [99]. Notably, in the latter study, $\mathrm{Cu}$ and $\mathrm{Zn}$ co-eluted from the reverse-phase HPLC column, suggesting that mixed-metal complexes were present. It is thus possible that differences in metal metabolism between native and expression host are amongst the reasons for our inability to detect copper-bound MT. Furthermore, the capacity of rainbow trout 
MTA for binding $\mathrm{Cu}(\mathrm{I})$ has been demonstrated in vitro [94]. Although MTs can form more or less stable complexes with almost any heavy metal in vitro, $\mathrm{Cu}(\mathrm{I})$ forms, after $\mathrm{Ag}(\mathrm{I})$, the thermodynamically most stable complexes. Nevertheless, not all MTs yield defined $\mathrm{Cu}(\mathrm{I})$ complexes when synthesised in vivo, an observation that has given rise to the notion that MT sequences have evolved to "fit" their cognate metal ion(s) [100]. It is self-evident that trigonal planar or digonal $\mathrm{Cu}(\mathrm{I})$, the dominant oxidation state in the cytosol and the only form found bound to MTs, requires different backbone conformations than the tetrahedrally coordinated $\mathrm{Cd}(\mathrm{II})$ and $\mathrm{Zn}(\mathrm{II})$; it is also evident that different backbone folds have different stabilities-hence, it is conceivable that more stable folds, or less flexible proteins may be formed with different metals. Our difficulties in isolating significant quantities of MT from copper-supplemented cultures parallels those encountered previously with mammalian MT2 [101]. This may indicate that like the majority of vertebrate MTs (at least MT1 and MT2) [35], CgMT has evolved to primarily deal with Zn(II). Equally, like other vertebrate MTs, CgMT is also well-suited to bind Cd(II). Whether this may have implications for biological function is discussed further in Section 4.

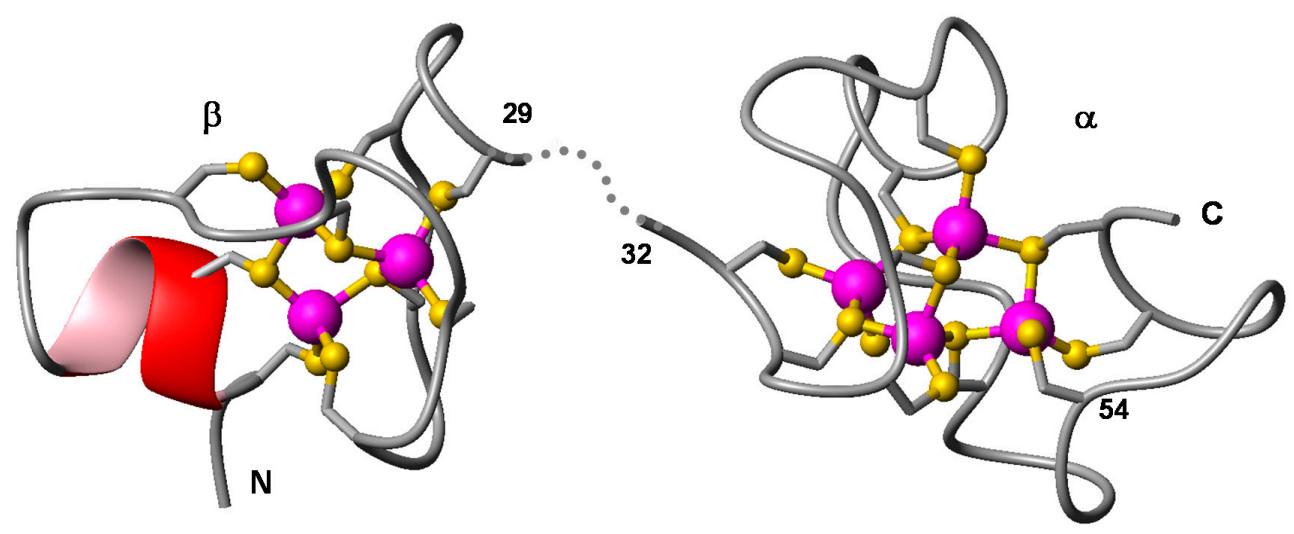

Figure 5. $3 \mathrm{D}$ model for $C$. gariepinus $\mathrm{MT}$ showing the canonical $\mathrm{M}(\mathrm{II})_{3} \mathrm{Cys}_{9}$ ( $\beta$ domain) and $\mathrm{M}(\mathrm{II})_{4} \mathrm{Cys}_{11}$ ( $\alpha$ domain) clusters. $\mathrm{N}$ - and $\mathrm{C}$-terminus are indicated. The initial models were generated in PHYRE ${ }^{2}$ [102] and are based on pdb entries $1 \mathrm{~m} 0 \mathrm{~g}$ and $1 \mathrm{~m} 0 \mathrm{j}$ ( $\alpha$ and $\beta$ domains of Notothenia coriiceps MTA, respectively [88]). The positions of the $\mathrm{Cd}(\mathrm{II})$ ions (magenta spheres) are also taken from these $\mathrm{pdb}$ entries. The two domains have been arranged in space by structural alignment with pdb entry $4 \mathrm{mt} 2$ (revised X-ray structure of rat liver MT [103]); the dotted line indicates the location for the linker residues 30 and 31, which are not resolved in the template NMR structures and hence also not in the model. The yellow spheres refer to thiolate sulphurs. The location of Cys54, which differs in all fish MTs from that of other vertebrate MTs, is also highlighted.

With nucleotide sequence determined, and functionality of the protein established, we are now in a position to explore $c g M T^{\prime}$ 's performance as a molecular biomarker.

\subsection{Concentrations of Heavy Metals in Fish Liver Samples}

Our previous study on metal contents in sediments from the Kafue River [81] indicated that besides $\mathrm{Cu}, \mathrm{Co}$ and $\mathrm{Mn}$ were also significantly enriched in sediments in the Copperbelt mining area, compared to the sediments in the unpolluted upstream reference site Chimfunshi (Table S1 and Figure S3 [81,104]). $\mathrm{Zn}$ and $\mathrm{Pb}$ were only slightly enriched, whereas $\mathrm{Cr}, \mathrm{Ni}, \mathrm{Cd}$ and $\mathrm{Hg}$ were less abundant in sediments from the mining area than in those from Chimfunshi. To establish whether the mining-related pollution is reflected in liver metal contents, we analysed the livers of 155 C. gariepinus fish caught in four different sites by Inductively-Coupled Plasma Mass Spectrometry (ICP-MS) after acid digestion of a small portion of each liver. Recoveries achieved by the chosen analytical method were determined using a certified reference material and ranged from $88 \%$ for $\mathrm{Cu}$ to $129 \%$ for $\mathrm{Zn}$ (Table S2). Analysis of heavy metal concentrations by sex did not show any significant 
differences and therefore data were not stratified by sex. Previous studies similarly concluded that sex had no influence on heavy metal accumulation in fish $[105,106]$. The full dataset is given in Table S3, and representative results are illustrated in Figure 6, with further plots compiled in Figure S4. The data are reported in $\mathrm{ppm}\left(\mu \mathrm{g} \cdot \mathrm{g}^{-1}\right)$, based on dry weight. The average water content of the livers was $74.12 \%$.
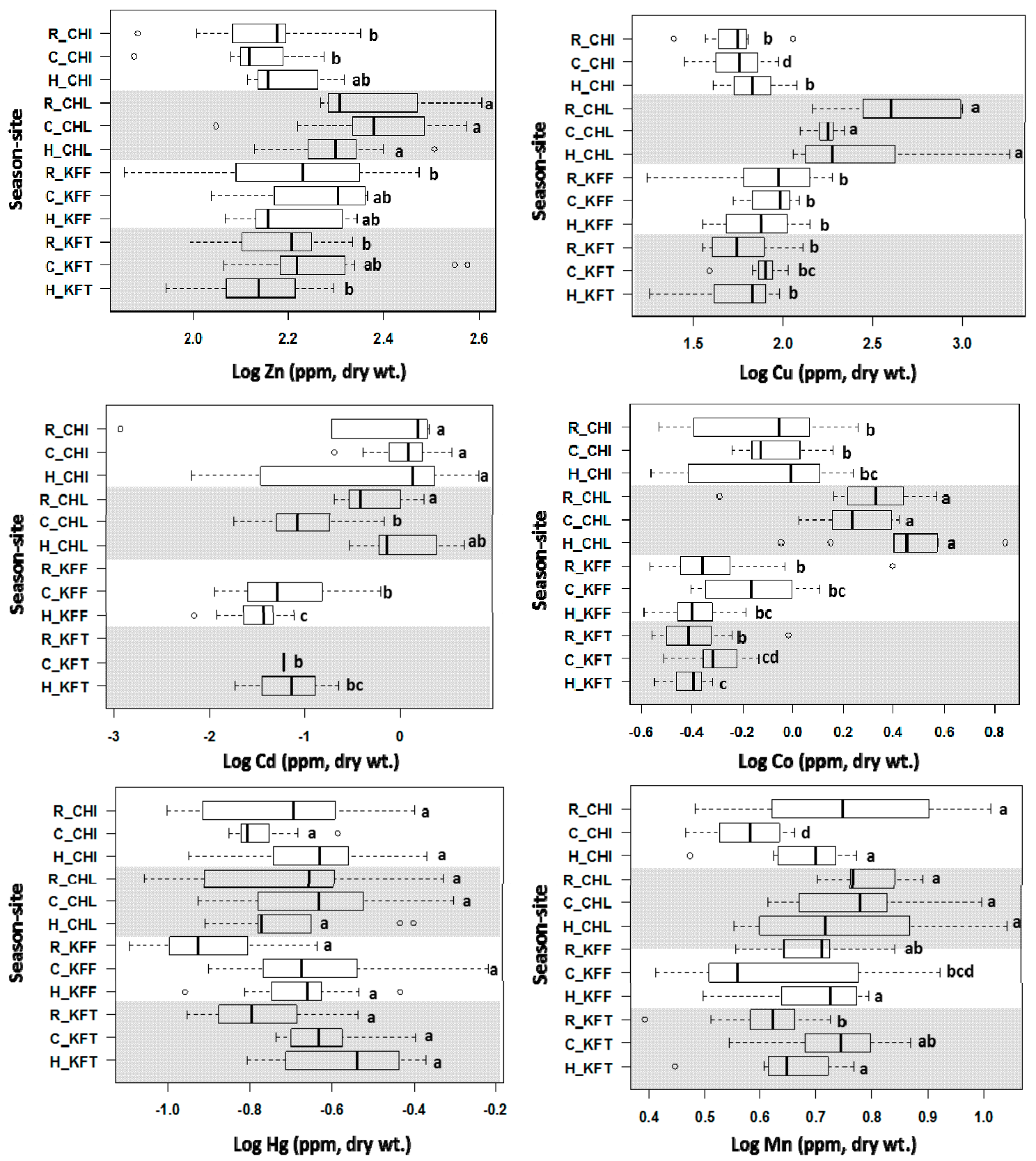

Figure 6. Levels of selected metals in liver tissue of $C$. gariepinus collected from four sample sites $(\mathrm{CHI}=$ Chimfunshi, $\mathrm{CHL}=$ Chililabombwe, $\mathrm{KFF}=$ Kafue Flats, $\mathrm{KFT}=$ Kafue Town $)$ during three distinct seasons $(\mathrm{R}$ = warm-rainy season, $\mathrm{C}=\mathrm{dry}$-cold season, $\mathrm{H}=$ dry-hot season); sites are distinguished by different shading. One-way ANOVA followed by a post-hoc Tukey's (HSD) test was applied to assess for spatial and seasonal differences in heavy metal levels. In the plots shown, levels for individual metals not connected by the same letter (" $a$ ", " $b$ " or " $c$ ") are significantly different $(p<0.05)$ between sites, as analysed for each individual season. The $\bigcirc$ symbols in these box-and-whiskers plots denote outliers. Note that the logarithmic $x$ axes scales are different for individual metals. In cases where no data are given, the respective metal was below detection limits. Also see Table S3 and Figure S4. 
$\mathrm{Hg}, \mathrm{Pb}, \mathrm{Cr}, \mathrm{Ni}$, and As levels in livers were low throughout, with As not detected at any of the study sites in any season. Ni was only detected at Chililabombwe in the warm-rainy season, and $\mathrm{Pb}$ was not detected in the warm-rainy season at any of the study sites. Overall, the mean heavy metal concentrations in liver samples at the study sites over the three seasons decreased in the order of: $\mathrm{Fe}>\mathrm{Zn}>\mathrm{Cu}>\mathrm{Se}>\mathrm{Al}>\mathrm{Mn}>\mathrm{Co}>\mathrm{Cd}>\mathrm{Hg}>\mathrm{Pb}>\mathrm{Cr}>\mathrm{Ni}$, As (Table S3).

The occasionally high variability of the results might be a consequence of variations in biotic factors such as age and size, which have been reported to have a moderate influence on heavy metal concentrations in fish [107]. In addition, up- or downstream migration of fish may result in contaminated fish caught in unpolluted sites, and vice versa [108]. Despite these complications, significant differences between sites are evident for several metals. In all three seasons, $\mathrm{Cu}$ and $\mathrm{Co}$ are significantly accumulated in livers of fish caught at Chililabombwe, the only site within the mining area where we were able to obtain fish. An increase in liver $\mathrm{Zn}$ levels is also evident at this site. The Co data are particularly clear, perhaps because normal Co concentrations in liver are much lower than either that of $\mathrm{Zn}$ or $\mathrm{Cu}$, which are naturally already quite abundant in fish liver [109]. All three metals were previously detected at higher levels at this site in sediments compared to the other three sites [81] (Figure S3); therefore, it may be concluded that $\mathrm{Cu}$, $\mathrm{Co}$ and perhaps also $\mathrm{Zn}$ are accumulated in livers as a consequence of pollution from mining activities. In contrast, corresponding differences in Mn levels in sediments were not reflected in Mn liver contents, which were fairly uniform around $5 \mathrm{ppm}$. It is likely that this different behaviour is due to differences in the homeostatic pathways for the different metals.

The comparatively high levels of $\mathrm{Cd}$ in sediments at Chimfunshi [81] were also reflected in increased $\mathrm{Cd}$ contents in livers in all three seasons. This is an interesting observation, because this site is considered pristine. It is possible that $\mathrm{Cd}$ concentrations in sediments, and consequently livers, are elevated due to the local geology and natural erosion of rocks, but further investigations are warranted. A trend towards higher Cd levels in fish livers is also apparent for Chililabombwe, compared to the Kafue Flats and Kafue Town sites, at least in the warm-rainy and dry-hot seasons. This could be a consequence of downstream migration of fish exposed to higher Cd levels at Chimfunshi and caught in Chililabombwe.

Figure 6 (and Figure S4) also allows observing seasonal variations of liver metal contents. Trends are hard to discern for either Chimfunshi or Chililabombwe, but further downstream at Kafue Flats and Kafue Town, the concentrations of $\mathrm{Co}, \mathrm{Cu}, \mathrm{Zn}, \mathrm{Cd}$, and $\mathrm{Hg}$ tended to be higher in the dry-cold season than in the rainy season. Such a trend has been observed previously [110]. Some heavy metals tend to accumulate more in fish samples in the dry-cold season due to the drought period which causes heavy metal salts to concentrate in water and ultimately accumulate in fish. Moreover, in the cold season most fish tend to settle at the bottom of the river for long periods of time and consume food from sediment which is the ultimate sink of heavy metals. In the case of $\mathrm{Cd}, \mathrm{Hg}$, and $\mathrm{Pb}$, concentrations in the dry-hot season were also higher than in the warm-rainy season. Such increases in heavy metal concentration in fish samples in the dry-hot season can be related to an increase in river water temperature which increases the evaporation rate of surface water, hence, an increase of heavy metal concentrations in water and ultimately in fish [111]. Moreover, the metabolic rate of fish increases with temperature [112,113], resulting in more frequent feeding sessions which may result in increased heavy metal intake [114].

The cursory observations made above may be refined by conducting correlation analyses between the liver contents of the various metals across all sites and seasons (Table 2). Cu was most strongly correlated positively with $\mathrm{Zn}$ and $\mathrm{Co}$, and these two metal ions are also strongly correlated with each other. $\mathrm{Mn}$ also correlated with $\mathrm{Co}$ and $\mathrm{Cu}$, which, despite the very small variations in the liver Mn data, may yet be a consequence of the elevated Mn concentration in sediment at Chililabombwe. $\mathrm{Pb}$ was also correlated strongly with $\mathrm{Cu}$ and $\mathrm{Co}$, but much more weakly with $\mathrm{Zn}$ and $\mathrm{Mn}$. These five metals were all elevated in sediment samples at Chililabombwe (Figure S3), and we conclude that this may at least partially account for these correlations. Fe, which was also enriched in Chililabombwe 
sediments, correlated strongly with three of these metals, namely $\mathrm{Co}, \mathrm{Cu}$, and $\mathrm{Zn}$, but not $\mathrm{Mn}$ or $\mathrm{Pb}$. $\mathrm{Cd}$ correlated only strongly with $\mathrm{Co}$; the origin of this correlation is unclear, although we note that both metals were at their lowest at Kafue Flats and Kafue Town. No strong correlations were observed for $\mathrm{Hg}$, and the essential metalloid Se showed only weak correlations to $\mathrm{Cu}, \mathrm{Co}, \mathrm{Zn}, \mathrm{Cd}$ and $\mathrm{Pb}$.

Table 2. Inter-metallic correlation coefficients (lower left-hand side) and $p$-values (in parentheses, upper right hand side) in fish liver samples at all four study sites over the three seasons. Significant correlations are highlighted with an asterisk $\left.*^{*} p<0.05\right)$ and in bold $(p<0.00001)$.

\begin{tabular}{|c|c|c|c|c|c|c|c|c|c|c|c|}
\hline & Al & $\mathrm{Cr}$ & Mn & $\mathrm{Fe}$ & Co & $\mathrm{Cu}$ & $\mathrm{Zn}$ & $\mathrm{Se}$ & $\mathrm{Cd}$ & $\mathrm{Hg}$ & $\mathbf{P b}$ \\
\hline $\mathrm{Al}$ & - & $(0.5719)$ & $(0.0426 *)$ & $(0.1794)$ & $(0.6672)$ & $(0.7432)$ & $(0.2225)$ & $(0.2097)$ & $\left(0.0087^{*}\right)$ & $(0.1707)$ & $(0.3160)$ \\
\hline $\mathrm{Cr}$ & -0.15 & - & $(0.7745)$ & $(0.5747)$ & $(0.7506)$ & $(0.4018)$ & $(0.7898)$ & (0.5735) & $(0.0380 *)$ & $(0.8042$ & $(0.6222)$ \\
\hline $\mathrm{Mn}$ & 0.18 & -0.08 & - & $(0.0169 *)$ & $(<0.00001 *)$ & $(<0.00001 *)$ & $(0.0032 *)$ & $(0.2207)$ & $(0.0285 *)$ & $(0.0056 *)$ & $(0.0010 *)$ \\
\hline $\mathrm{Cu}$ & 0.03 & 0.22 & 0.36 & 0.41 & 0.66 & - & $(<0.00001 *)$ & $\left(0.0019^{*}\right)$ & $0.0290 *)$ & $(0.0344 *)$ & $(<0.00001 *)$ \\
\hline $\mathrm{Zn}$ & 0.11 & 0.07 & 0.26 & 0.60 & 0.41 & 0.66 & - & $(0.0453 *)$ & $(0.4079)$ & $\left(0.0017^{*}\right)$ & $(0.1168)$ \\
\hline $\mathrm{Se}$ & -0.11 & 0.15 & 0.11 & 0.14 & 0.31 & 0.28 & 0.18 & & $0.0003 *)$ & $(0.8902)$ & $\left(0.0319^{*}\right)$ \\
\hline $\mathrm{Cd}$ & -0.29 & 0.54 & 0.24 & 0.03 & 0.56 & 0.24 & -0.09 & 0.39 & - & $(0.6306)$ & $(0.0109 *)$ \\
\hline
\end{tabular}

Rationalising such correlation data for biological samples is not straightforward, as variations in metal contents in biological tissues do not only reflect sources of and pollution from individual metals, but also differences in metal metabolism. To investigate to what extent sediment was a major source for individual metals accumulated in C. gariepinus livers, a correlation analysis between metal contents in fish liver samples and river sediments collected at the same sites and the same times (see Section 2.1; data taken from [81]) was carried out (Table S4). Correlations were observed for Al, Mn, $\mathrm{Cu}, \mathrm{Co}$, and $\mathrm{Cd}$, indicating that, where these metals were elevated in fish livers, sediment was likely an important source of these metals, presumably due to the bottom-feeding habits of C. gariepinus. The correlations for $\mathrm{Cu}$ and Co were strongest; this is mainly a consequence of the clearly elevated levels in sediments and livers at Chililabombwe. The correlation for $\mathrm{Zn}$ is much weaker; this may be a consequence of this metal being only slightly enriched in sediments at Chililabombwe, normal liver levels of $\mathrm{Zn}$ being relatively high in any case, and the homeostasis of the essential $\mathrm{Zn}$ being very well controlled. Interestingly, the correlation values for toxic $\mathrm{Pb}$ were similar to those for $\mathrm{Zn}$. Pb was also slightly enriched in sediments at Chililabombwe (Figure S3), explaining the existence of a correlation. No significant correlations were observed for $\mathrm{Cr}, \mathrm{Fe}$, Se, and $\mathrm{Hg}$; thus, the composition of the sediments was not a major factor in determining the levels of these elements in fish livers.

In summary, the metal analysis data indicate clearly that fish at Chililabombwe have elevated levels of $\mathrm{Cu}, \mathrm{Co}, \mathrm{Fe}, \mathrm{Zn}$ and $\mathrm{Pb}$ (Figure 6 and Figure S4) in their livers, and that for $\mathrm{Co}$ and $\mathrm{Cu}$, this is at least in part a consequence of higher enrichment in sediments (Tables S1 and S5, and Figure S3). We next explored whether variations in liver metal contents are reflected in MT expression to test the utility of $\operatorname{cg} M T$ expression as a biomarker for metal pollution.

\subsection{MT Gene Expression Levels in Liver of C. gariepinus}

The same 155 livers as analysed for heavy metal contents were used to quantify the relative expression of $c g M T$ in the liver of $C$. gariepinus (Figure 7). Although some studies have reported sex-dependent differences in MT expression levels [28], no sex difference was apparent in cgMT expression levels in the livers used in our study (data not shown), and therefore data were not stratified by sex. 


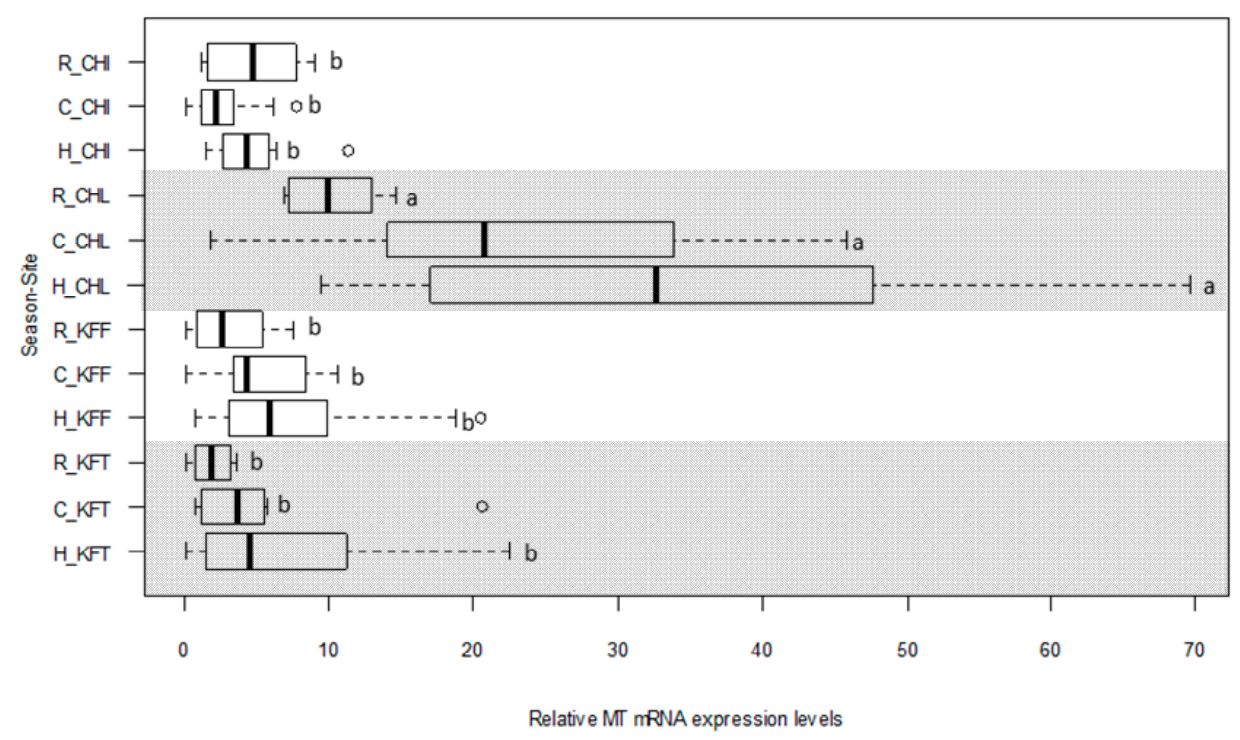

Figure 7. $C g M T$ mRNA expression levels in liver tissue of $C$. gariepinus collected from 4 sample sites $(\mathrm{CHI}=$ Chimfunshi, $\mathrm{CHL}=$ Chililabombwe, $\mathrm{KFF}=$ Kafue Flats, $\mathrm{KFT}=$ Kafue Town $)$ during three distinct seasons $(\mathrm{R}=$ warm-rainy season, $\mathrm{C}=$ dry-cold season, $\mathrm{H}=$ dry-hot season). CgMT levels were determined by qPCR (7500 Fast Real-Time PCR System, Applied BioSystems) from each season/site condition, each of which consisted of 10-18 individual biological replicates (see Table S3). CgMT quantification was performed using three technical replicates per sample and was normalised to $\beta$-actin. One-way ANOVA followed by a post-hoc Tukey's (HSD) test was applied to assess for spatial and seasonal differences in MT expression levels. Different letters (" $a$ " and " $b$ ") indicate a statistically significant difference $(p<0.05)$ between sites in each season. The $\bigcirc$ symbols in this box-and-whiskers plot denote outliers.

CgMT expression levels, expressed relative to the sample that showed the lowest level (collected from Chimfunshi), ranged from 2.00 (Kafue Town in the warm-rainy season) to 34.2 (Chililabombwe in the dry-hot season). CgMT expression levels decreased by site and season in the order: Chililabombwe (dry-hot season) $>$ Chililabombwe (dry-cold season) > Chililabombwe (warm-rainy season) $>$ Kafue Flats (dry-hot season) $>$ Chimfunshi (warm-rainy season) $>$ Kafue Town (dry-hot season) $>$ Chimfunshi (dry-hot season) $>$ Kafue Flats (dry-cold season) $>$ Kafue Flats (warm-rainy season) $>$ Chimfunshi (dry-cold season) $>$ Kafue Town (warm-rainy season). Hence, the Chililabombwe site in the mining area showed the highest $c g M T$ transcript levels in all three seasons. No significant site differences in $c g M T$ expression levels were observed amongst fish from Chimfunshi (site upstream from the Copperbelt mining area), Kafue Flats and Kafue Town (sites far downstream). Compared to Chimfunshi, $c g M T$ mRNA expression levels in fish from Chililabombwe were increased approximately 2.2-fold in the warm-rainy season, 8.9-fold in the dry-cold season and 7.1-fold in the dry-hot season. Considering seasonal variations, there is a trend towards lower expression levels in the warm-rainy season (except at Chimfunshi), similar to the trends observed for most metal ions (Section 2.4, Figure 6).

Hence, given the elevated levels of metals in the livers from Chililabombwe, and similarities in seasonal trends (Figure 6 and Figure S4, and Table S3), it can be qualitatively confirmed that in the catfish C. gariepinus, elevated metals in liver are indeed reflected in hepatic MT expression. A more quantitative picture may be obtained by conducting a correlation analysis between $c g M T$ expression levels and heavy metals in liver tissue across all seasons, carried out separately for each of the four sites (Table 3). A correlation analysis across all sites and seasons can be found in Table S5. 
Table 3. Pearson correlation coefficients $(r)$ and $p$-values for correlation between $c g M T$ expression levels and heavy metals in liver tissue of 155 C. gariepinus fish collected over three seasons, conducted separately for each of four sites.

\begin{tabular}{ccccccccc}
\hline \multirow{2}{*}{ Metal } & \multicolumn{2}{c}{ Chimfunshi } & \multicolumn{2}{c}{ Chililabombwe } & \multicolumn{2}{c}{ Kafue Flats } & \multicolumn{2}{c}{ Kafue Town } \\
\cline { 2 - 8 } & $\boldsymbol{r}$ & $\boldsymbol{p}$ & $\boldsymbol{r}$ & $\boldsymbol{p}$ & $\boldsymbol{r}$ & $\boldsymbol{p}$ & $\boldsymbol{r}$ & $\boldsymbol{p}$ \\
\hline $\mathrm{Al}$ & 0.20 & 0.2896 & 0.06 & 0.7389 & 0.10 & 0.5186 & 0.15 & 0.2775 \\
$\mathrm{Cr}$ & - & - & -0.19 & 0.2840 & - & - & - & - \\
$\mathrm{Mn}$ & 0.29 & 0.1102 & 0.09 & 0.5927 & -0.09 & 0.5530 & -0.09 & 0.5326 \\
$\mathrm{Fe}$ & 0.05 & 0.7673 & -0.32 & 0.0608 & 0.17 & 0.2675 & 0.23 & 0.0892 \\
$\mathrm{Co}$ & 0.08 & 0.6564 & 0.20 & 0.2429 & -0.16 & 0.2867 & 0.04 & 0.7789 \\
$\mathrm{Cu}$ & $\mathbf{0 . 3 9}$ & $\mathbf{0 . 0 2 7 0} *$ & $\mathbf{0 . 4 0}$ & $\mathbf{0 . 0 1 6 2} *$ & $\mathbf{0 . 3 7}$ & $\mathbf{0 . 0 1 3 5}$ & $\mathbf{0 . 5 8}$ & $<\mathbf{0 . 0 0 0 1} *$ \\
$\mathrm{Zn}$ & $\mathbf{0 . 5 2}$ & $\mathbf{0 . 0 0 2 4} *$ & -0.04 & 0.8096 & $\mathbf{0 . 4 5}$ & $\mathbf{0 . 0 0 2 2} *$ & $\mathbf{0 . 4 7}$ & $\mathbf{0 . 0 0 0 3}$ \\
$\mathrm{Se}$ & -0.12 & 0.5094 & $\mathbf{0 . 5 7}$ & $\mathbf{0 . 0 0 0 3} *$ & -0.03 & 0.8677 & 0.10 & 0.4710 \\
$\mathrm{Cd}$ & -0.34 & 0.0572 & $\mathbf{0 . 4 0}$ & $\mathbf{0 . 0 1 7 2} *$ & 0.08 & 0.6277 & - & - \\
$\mathrm{Hg}$ & 0.22 & 0.2197 & -0.11 & 0.5482 & $\mathbf{0 . 3 8}$ & $\mathbf{0 . 0 1 0 1} *$ & $\mathbf{0 . 3 5}$ & $\mathbf{0 . 0 0 9 7} *$ \\
$\mathrm{~Pb}$ & -0.26 & 0.1493 & 0.16 & 0.3699 & 0.18 & 0.2410 & - & - \\
\hline
\end{tabular}

Significant correlations $(p<0.05)$ are marked with * and are highlighted in bold. Entries with no data concern metals that were not detected at the respective site.

As has been pointed out [20], in field studies, the bioindicator organism is typically exposed to mixtures of metals, or indeed other pollutants, making it impossible to attribute MT induction to (a) particular metal(s). For the following considerations, it is therefore imperative to bear in mind that the data in Table 3 do not provide an analysis of whether or not $c g M T$ responds to the levels of a particular metal ion, but at most which metal ion(s) govern the expression of $c g M T$ under the prevailing field study conditions. The most fundamental hypothesis that may underlie the data in Table 3 states that the presence of a particular metal induces MT transcription. It has been known for a long time that many metals can induce MT transcription, including $\mathrm{Zn}, \mathrm{Cu}, \mathrm{Cd}, \mathrm{Hg}, \mathrm{Pb}, \mathrm{Mn}, \mathrm{Fe}$, $\mathrm{Ni}, \mathrm{Co}[28,30,40,50,115,116]$ and As [117]. In contrast, selenite may downregulate MT expression [118]. Thus, in principle, almost any of the metal ions under study might contribute to MT expression levels.

Clearly, in the non-polluted site Chimfunshi, the only significant correlations observed were those with liver $\mathrm{Zn}$ and $\mathrm{Cu}$. Strong correlation with $\mathrm{Zn}$ was also observed at Kafue Town and Kafue Flats, but this was completely lost in Chililabombwe, the site within the mining area, even though the levels of $\mathrm{Zn}$ in livers were elevated in fish from this site (Figure 6). It remains an interesting question whether these elevated levels of $\mathrm{Zn}$ in the livers from Chililabombwe are cause or consequence of elevated MT protein levels, as MTs are known to contribute to metal retention [119].

These data display various parallels with literature reports, for example, positive correlations with hepatic $\mathrm{Cu}$ levels were reported for perch [120], rainbow trout [48], eel [55,107], golden-grey mullet [121], and gilt-head bream [60]. Correlations with hepatic $\mathrm{Zn}$ also have been observed frequently, for example also in eel [55], striped red mullet [121] and feral perch, gudgeon and roach [122]. Given that $\mathrm{Zn}$ and $\mathrm{Cu}$ also are two of the metals most frequently found associated with MTs in vivo [30,99], these correlations are within expectations, irrespective of our inability to detect copper-binding forms of CgMT in our recombinant system.

In addition, correlations were observed for $\mathrm{Cd}$ and Se at Chililabombwe, and for $\mathrm{Hg}$ at Kafue Flats and Kafue Town. $\mathrm{Cd}$ has been repeatedly proven to be a strong inducer of MT expression, including in fish $[24,36,55,60,115]$. The Chililabombwe site did not have particularly high average Cd levels, neither in sediments, nor in livers (Tables S1 and S3). Since the analysis in Table 3 correlates data for individual fish, it is possible that the liver $\mathrm{Cd}$ levels differed significantly between fish depending on their life history, and that elevated $\mathrm{Cd}$ was an additional contributor to increased liver $c g M T$ expression. The origin of the strong positive correlation with Se at Chililabombwe is unclear. It is unlikely to be related to pollution with selenium, but elevated liver selenium might be a consequence of copper-induced oxidative stress leading to upregulation of antioxidant selenoproteins [123]. 
Although average $\mathrm{Hg}$ values at Kafue Flats and Kafue Town were not significantly elevated in fish livers compared to those from the other sites (Figure 6 and Table S3), correlations between liver $\mathrm{Hg}$ levels and MT expression were apparent within these two sites. The plot for $\mathrm{Hg}$ in Figure 6 hints at seasonal differences in liver Hg levels at Kafue Flats and Kafue Town, with a trend towards lower levels in the warm-rainy season. Mercury exposure leading to MT induction has been observed previously [124-126]. Whilst the average values did not display statistically significant differences, it appears possible that small seasonal variations in $\mathrm{Hg}$ levels may be contributing to MT induction levels, and this trend should be followed up in the future.

No correlations were observed for $\mathrm{Al}, \mathrm{Cr}, \mathrm{Mn}, \mathrm{Fe}, \mathrm{Co}, \mathrm{Ni}$ and $\mathrm{Pb}$. With the exception of $\mathrm{Al}$, all of these metals have been reported to induce MT synthesis in various organisms [40,115,116,127-129]. The absence of correlations with these metals in our study has various causes: the levels of $\mathrm{Al}, \mathrm{Cr}, \mathrm{Mn}$, $\mathrm{Ni}$ and $\mathrm{Pb}$ are low and fairly invariant; those of $\mathrm{Fe}$ are high throughout; and, although $\mathrm{Co}$ is elevated at Chililabombwe (Figure 6), the per-site correlation analysis shows that, within a given site, this metal is not a major contributor to MT induction in the given background of high $\mathrm{Cu}$. If data are analysed across all sites (Table S5), a correlation with Co is apparent (along with weaker correlations for all metals that are elevated in livers from this site); this is due to elevated liver Co levels at Chililabombwe, which coincide with elevated $c g M T$ expression.

In summary, expression of MT in wild C. gariepinus correlates with liver $\mathrm{Cu}$ and $\mathrm{Zn}$ levels in non-contaminated conditions, whilst extraordinarily high levels of $\mathrm{Cu}$ abrogate the correlation with $\mathrm{Zn}$. Further correlations with low levels of toxic $\mathrm{Cd}$ and $\mathrm{Hg}$ indicate that more subtle pollution may also be picked up, warranting future studies.

\subsection{Suitability of C. gariepinus Liver MT mRNA as a Biomarker}

To ultimately assess whether $c g M T$ expression can be used as a biomarker of pollution, we have carried out further Pearson correlation analyses to explore links between metals in sediment and cgMT expression (Table S6). Inclusion of all four sites in the analysis shows that $c g M T$ expression correlates with all metals that are elevated (Mn, $\mathrm{Co}, \mathrm{Cu}, \mathrm{Zn}$, and Pb; Figure S3) in sediments at the polluted site Chililabombwe.

Pollution and ecological risks are always consequences of mixtures of pollutants; therefore, quantitative indices that summarise overall pollution and its impacts are defined in Ecotoxicology [130]. A successful biomarker may be expected to also correlate well with such cumulative indices. To explore this expectation, we have calculated correlations between $c g M T$ expression, the "pollution load index" (PLI), and the "potential exological risk index" (RI). PLI and RI values are reported in reference [81], and were derived from the sediment metal data for each site/season combination apart from the uncontaminated site Chimfunshi, which served as reference site. (PLI values are generally calculated from the contamination factors for each metal $(\mathrm{CF}=$ concentration(site)/concentration(reference site) $)$, using the following relationship [131]: $\mathrm{PLI}=\mathrm{CF}($ metal1 $) \times \mathrm{CF}($ metal2 $) \times \ldots)^{1 / \mathrm{n}}$. RI values are calculated from the sum of the potential ecological risk factors $(\mathrm{Er}=\operatorname{Tr} \times$ concentration(site)/concentration(reference site) ) for each metal, where $\operatorname{Tr}$ is the "toxic response factor" and depends on each metal's toxicity (for example, $\operatorname{Tr}(\mathrm{Hg})=40$, and $\operatorname{Tr}(\mathrm{Zn})=1$ [132]).) PLI aims to give a summary reflection of pollution from a mixture of contaminating metals, whilst RI concerns their impact and thus takes into account their toxicity. PLI and RI values for each of the nine site/season combinations are tabulated in Table S7 (compiled from reference [81]). Liver MT expression in fish caught at these sites in each of three seasons was strongly correlated with pollution as expressed by the PLI $(r=0.45 ; p<0.0001)$ as well as with potential ecological risk $(r=0.67$; $p<0.0001$ for RI). Both correlations are largely a reflection of the high levels of pollution from $\mathrm{Cu}$ at Chililabombwe (see also Table S4).

In summary, despite considerable variations in the data for both metal levels and MT expression, probably due to a range of biotic factors, the elevation of $c g M T$ expression in fish from the polluted Chililabombwe site was unequivocal. We conclude that, within the context of our cross-sectional study, 
$c g M T$ expression in the livers of $C$. gariepinus fish, as measured by quantifying mRNA, can serve as a suitable biomarker of pollution and ecological risk, and could be developed into a sensitive tool for biomonitoring purposes, especially in the context of mitigating the environmental effects of mining activities in the Copperbelt region.

\section{Materials and Methods}

\subsection{Fish Collection, Preparation and Sampling}

C. gariepinus weighing between 600 to $1200 \mathrm{~g}$ were sampled in the warm-rainy, dry-cold season and dry-hot seasons in 2014. A minimum of 10 individual fish per site in each season were randomly purchased from fishermen and initially stratified according to sex. Each fish was humanely killed and thoroughly cleaned with distilled water before dissection. A ventral midline incision was made and liver samples were dissected. Each of 155 livers was used in heavy metal determination and MT expression analysis. Samples for heavy metal analysis were placed in aluminium foil. For the determination of metallothionein mRNA levels, about $1 \mathrm{~cm}^{3}$ of each liver was placed in an Eppendorf tube containing $1 \mathrm{~mL}$ RNAlater ${ }^{\circledR}$ (Sigma Aldrich, Irvine, UK). All samples were frozen and transported in liquid nitrogen and then stored at $-80^{\circ} \mathrm{C}$ until analysis.

\subsection{Total RNA Isolation and Reverse Transcription Reaction}

Total RNA was isolated from liver using TRI Reagent (Sigma Aldrich) according to the manufacturer's protocol. About 18 to $20 \mathrm{mg}$ of liver tissue was crushed in $1 \mathrm{~mL}$ of TRI Reagent using a hand-held RNase-free pellet pestle (VWR International Limited, Lutterworth, UK) until the tissue was homogenised. The quantity and integrity of isolated RNA was checked on $1 \%$ agarose gel stained with GelRed ${ }^{\mathrm{TM}}$ Nucleic Acid Gel Stain (VWR International Limited) in $1 \times$ Tris-acetate-EDTA (TAE) buffer and by spectrophotometric measurement using NanoDrop Lite (ThermoFisher Scientific, Rugby, UK). Total RNA was stored at $-80^{\circ} \mathrm{C}$ until use.

The cDNA was synthesised from total RNA using the RevertAid First Strand cDNA Synthesis Kit (ThermoFisher Scientific). The $12 \mu \mathrm{L}$ reaction mixture contained: $3 \mu \mathrm{g}$ of total RNA, $1 \mu \mathrm{L}$ of $100 \mu \mathrm{M}$ oligo $(\mathrm{dT})_{18}$ primer and nuclease free water (ThermoFisher Scientific). The mixture was incubated at $65{ }^{\circ} \mathrm{C}$ for $5 \mathrm{~min}$, and then at $0{ }^{\circ} \mathrm{C}$ for $2 \mathrm{~min}$. Thereafter, $4 \mu \mathrm{L}$ of $5 \times$ RT Buffer, 20 units of RiboLock RNase inhibitor, $2 \mu \mathrm{L} 10 \mathrm{mM}$ dNTPs and $200 \mathrm{U}$ of RevertAid ${ }^{\mathrm{TM}}$ Premium Reverse Transcriptase were added. The reaction mixture was incubated at $42{ }^{\circ} \mathrm{C}$ for $60 \mathrm{~min}$ and terminated at $70{ }^{\circ} \mathrm{C}$ for $10 \mathrm{~min}$. The obtained cDNA was stored at $-20^{\circ} \mathrm{C}$ until analysis.

\subsection{Primer Design and Reverse Transcription Polymerase Chain Reaction (RT-PCR)}

In order to amplify cDNA encoding C. gariepinus metallothionein (cgMT), degenerate primers were designed using sequences deposited in GenBank at NCBI encoding MTs from closely related species in the same order as C. gariepinus-Siluriformes: Clarias macrocephalus (accession No JX312865.1) and Pelteobagrus fulvidraco (accession No FJ418583.1). The primers were as follows: forward primer $5^{\prime}$-ARYKWSMTYTWTTTGRAAAGCGA-3' and reverse primer 5'-YMWSRTGMYRRKARTSTTGGAGT-3' (IDT Integrated DNA Technologies, Leuven, Belgium), where $\mathrm{R}=\mathrm{A}$ or $\mathrm{G}, \mathrm{Y}=\mathrm{C}$ or $\mathrm{T}, \mathrm{K}=\mathrm{G}$ or $\mathrm{T}, \mathrm{W}=\mathrm{A}$ or $\mathrm{T}, \mathrm{S}=\mathrm{G}$ or $\mathrm{C}$ and $\mathrm{M}=\mathrm{A}$ or $\mathrm{C}$. The product size was around $200 \mathrm{bp}$. In addition, to check the $C$. gariepinus $\beta$-actin (cg $\beta$-actin) sequence, a partial cDNA for this gene was also generated, using primers designed based on its sequence available at GenBank (accession No KJ722167.1). The expected product with a size of $396 \mathrm{bp}$ was amplified with forward $5^{\prime}$-GATGATGAAATCGCCGCACT- ${ }^{\prime}$ and reverse $5^{\prime}$-ATACATGGCTGGGGTGTTGA-3' primers (IDT Integrated DNA Technologies). To amplify cgMT and $c g \beta$-actin cDNA, the RT-PCR reactions were prepared using the Phusion High-Fidelity PCR Kit (ThermoFisher Scientific). The reaction mixture included: $1.5 \mu \mathrm{L}$ of single-stranded cDNA as template, $0.4 \mu \mathrm{L}$ of $10 \mu \mathrm{M}$ forward and $0.4 \mu \mathrm{L}$ of $10 \mu \mathrm{M}$ reverse primers, $0.4 \mu \mathrm{L}$ of $10 \mathrm{mM}$ dNTPs, $4 \mu \mathrm{L} 5 \times$ buffer, $0.4 \mathrm{U}$ of Phusion 
High-Fidelity DNA Polymerase and nuclease free water (ThermoFisher Scientific) in a total volume of $20 \mu \mathrm{L}$. The cycling conditions were as follows: initial denaturation: $98^{\circ} \mathrm{C}$ for $30 \mathrm{~s}$; denaturation: $98^{\circ} \mathrm{C}$ for $10 \mathrm{~s}$, annealing: $52{ }^{\circ} \mathrm{C}$ for $40 \mathrm{~s}$ and extension: $72{ }^{\circ} \mathrm{C}$ for $40 \mathrm{~s}$ for 30 cycles; final extension at $72{ }^{\circ} \mathrm{C}$ for $5 \mathrm{~min}$. The PCR products were visualised on a $2 \%$ agarose gel. PCR products were extracted from the gels using QIAquick Gel Extraction Kit (Qiagen, Hilden, Germany) according to the manufacturer's protocol. The purified PCR products were then ligated with pJET1.2 blunt vector (CloneJET PCR Cloning Kit, ThermoFisher Scientific) according to the manufacturer's protocol and sent to GATC Biotech (Konstanz, Germany) for sequencing.

\subsection{Expression and Purification of Recombinant CgMT}

PCR was performed to amplify the open reading frame of $C$. gariepinus metallothionein on the pJET1.2 plasmid bearing the partial cDNA of $c g M T$ using sequence-specific primers (IDT Integrated DNA Technologies, Leuven, Belgium) containing an NdeI (forward) or an XhoI (reverse) restriction site, respectively: forward 5'-AAACATATGGACCCCTGCGAGTGTTCAAAG-3' and reverse 5'-AAACTCGAGTCACTGACAGCACTTGGAATCAC-3' (restriction sites are underlined). The PCR mixture contained: $1.5 \mu \mathrm{L}$ plasmid DNA as a template, $0.6 \mu \mathrm{L}$ of $10 \mu \mathrm{M}$ forward and $0.6 \mu \mathrm{L}$ of $10 \mu \mathrm{M}$ reverse primers, $0.4 \mu \mathrm{L}$ of $10 \mathrm{mM}$ dNTPs, $4 \mu \mathrm{L} 5 \times$ buffer, $0.4 \mathrm{U}$ of Phusion High-Fidelity DNA Polymerase (ThermoFisher Scientific) and nuclease free water (ThermoFisher Scientific) in a total volume of $20 \mu \mathrm{L}$. The thermal cycling conditions were as follows: initial denaturation: $98^{\circ} \mathrm{C}$ for $30 \mathrm{~s}$; denaturation: $98^{\circ} \mathrm{C}$ for $10 \mathrm{~s}$, annealing: $52{ }^{\circ} \mathrm{C}$ for $30 \mathrm{~s}$ and extension: $72{ }^{\circ} \mathrm{C}$ for $30 \mathrm{~s}$ for 30 cycles; final extension at $72{ }^{\circ} \mathrm{C}$ for $5 \mathrm{~min}$. After digestion with NdeI and XhoI, the PCR product was ligated into pET21a(+) bacterial expression vector (Novagen, Darmstadt, Germany). In order to confirm that the open reading frame was inserted correctly and that there were no mutations, sequencing of the isolated plasmids was performed (GATC Biotech). The obtained construct was named pET-CgMT.

CgMT was recombinantly expressed in E. coli Rosetta 2 (DE3) pLysS (Novagen) in the presence of $\mathrm{Zn}^{2+}, \mathrm{Cd}^{2+}$ or $\mathrm{Cu}^{2+}$ (the latter under low aeration to promote levels of $\mathrm{Cu}(\mathrm{I})$ ) [91]. Overnight cultures of transformed bacteria were diluted 1:100 $(v / v)$ in LB medium containing chloramphenicol $(34 \mu \mathrm{g} / \mathrm{mL})$ and ampicillin $(100 \mu \mathrm{g} / \mathrm{mL})$. When the optical density of the culture had reached ca. $0.6-0.7$ at $600 \mathrm{~nm}$, the expression of protein was induced by adding $0.5 \mathrm{mM}$ isopropyl $\beta$-D-1-thiogalactopyranoside (IPTG; Sigma-Aldrich, Irvine, UK) and $\mathrm{ZnSO}_{4}$ to a final concentration of $0.5 \mathrm{mM}, \mathrm{CdSO}_{4}$ to a final concentration of $0.3 \mathrm{mM}$, or $\mathrm{CuSO}_{4}$ to a final concentration of $0.1 \mathrm{mM}$. The cultures were incubated at $15{ }^{\circ} \mathrm{C}$ overnight before harvesting by centrifugation. The cell pellet was suspended in lysis buffer (50 mM Tris, $100 \mathrm{mM} \mathrm{KCl,} 3 \mathrm{mM}$ DTT, $0.5 \%$ Triton X-100 and either $\mathrm{Zn}^{2+}$ or Cd $^{2+}$ to a final concentration of $1 \mathrm{mM}$ as appropriate to the metal added during protein expression, $\mathrm{pH}$ 8.5) and cells were disrupted using a cell disruptor (Constant Systems Limited, Daventry, UK) at a pressure of $20 \mathrm{kpsi}$. Cell lysate was separated from cell debris by centrifugation at $11,000 \mathrm{rpm}$ and $4{ }^{\circ} \mathrm{C}$ for $30 \mathrm{~min}$, filtered through Millipore syringe filters $(0.22 \mu \mathrm{M})$ and purified by fast protein liquid chromatography (FPLC) (GE Healthcare Äkta Purifier, Little Chalfont, UK) using a size exclusion column (SEC) (HiLoad 16/60 Superdex 75, Amersham Biosciences, Little Chalfont, UK) equilibrated with $20 \mathrm{mM} \mathrm{NH}_{4} \mathrm{HCO}_{3}$ buffer. For further purification, fractions from SEC were combined and loaded onto an anion exchange column (AEX) (HiTrap Q XL 5 mL, GE Healthcare, Little Chalfont, UK). The column was washed with $25 \mathrm{~mL}$ of high salt buffer $\left(1 \mathrm{M} \mathrm{NaCl}, 20 \mathrm{mM} \mathrm{NH}_{4} \mathrm{HCO}_{3}, \mathrm{pH} 9.0\right)$ followed by equilibration with $25 \mathrm{~mL}$ of low salt buffer $\left(20 \mathrm{mM} \mathrm{NH}_{4} \mathrm{HCO}_{3}, \mathrm{pH}\right.$ 9.0). The elution of the protein was monitored by measuring absorbance at 220 and $280 \mathrm{~nm}$. Selected fractions were pooled and desalted using PD10 desalting columns (Sephadex G-25, GE Healthcare) with $10 \mathrm{mM} \mathrm{NH}_{4} \mathrm{HCO}_{3}$ buffer. Next, eluates from PD10 columns were analysed for metal and sulphur contents by inductively-coupled plasma optical emission spectroscopy (ICP-OES, Perkin-Elmer Optima 5300 DV, Model S10, Llantrisant, UK; vide infra), and/or analysed on SDS-PAGE gels. Proteins were resolved on precast $4-15 \%$ Mini-PROTEAN ${ }^{\circledR} \mathrm{TGX}^{\mathrm{TM}} \mathrm{Gel}$ (Bio-Rad, Watford, UK) in TGS (Tris/Glycine/SDS, pH 8.3; Bio-Rad) buffer and visualised by silver 
staining. Protein concentration was determined via measuring $\mathrm{S}$ content by ICP-OES or by measuring thiol content using Ellman's reaction [133] after demetallation with 1 mM EDTA.

\subsection{Analysis of Metal-Binding Stoichiometries of Recombinant CgMT}

The contents of $\mathrm{S}, \mathrm{Zn}$ and $\mathrm{Cd}$ in samples were determined by ICP-OES by measuring $\mathrm{S}$ at 181.980 and $180.675 \mathrm{~nm}, \mathrm{Cd}$ at 228.806 and $214.449 \mathrm{~nm}$ and $\mathrm{Zn}$ at 206.204 and $213.863 \mathrm{~nm}$. Mixed element calibration standards were prepared in the range of $0.2-5 \mathrm{ppm}$ from commercial stocks (TraceCERT, Sigma-Aldrich). All samples and standards were prepared in $0.1 \mathrm{M} \mathrm{HNO}_{3}$ (ultrapure $70 \% \mathrm{HNO}_{3}$ purified in-house by sub-boiling point distillation of reagent-grade $\mathrm{HNO}_{3}$ ).

Prior to analysis by electrospray ionisation (ESI) time-of-flight mass spectrometry (MicrOTOF, Bruker Daltonics, Bremen, Germany), samples were concentrated to 20-30 $\mu \mathrm{M}$ using Amicon Ultra-4 $3000 \mathrm{Da}$ MWCO centrifugal filters. The parameters for ESI-MS were as follows: source temperature $468 \mathrm{~K}$, mass spectral voltage parameters: $210 \mathrm{~V}$ capillary exit, $450 \mathrm{~V}$ hexapole RF, 1:70 V skimmer, 1:19 $\mathrm{V}$ hexapole. MS data were acquired in the positive mode in the range of 500-3500 mass to charge $(\mathrm{m} / \mathrm{z})$ ratio with an average mass spectrum being generated from $2 \mathrm{~min}$ of analysis time. For the mass spectra of metallated proteins, the samples in $10 \mathrm{mM} \mathrm{NH}_{4} \mathrm{HCO}_{3}$ at $\mathrm{pH} 7.8$, were mixed with $10 \%(v / v)$ methanol and injected directly into the spectrometer using a syringe pump at a flow rate $240 \mu \mathrm{L} / \mathrm{h}$. In order to obtain mass spectra for the apo form of the protein, concentrated formic acid was added to give a $\mathrm{pH}$ of ca. 2. Deconvoluted spectra were generated from the most intense peak in the raw spectra and were analysed using Data Analysis 4.0 software (Bruker Daltonics, Bremen, Germany).

\subsection{Quantitative Real-Time PCR}

MT mRNA levels were determined by quantitative real-time PCR (7500 Fast Real-Time PCR System, Applied BioSystems, Foster City, CA, USA) using ROX qPCR master mix (ThermoFisher Scientific). Custom primers and probes (Sigma Aldrich) for $c g M T$ and $c g \beta$-actin were designed using ProbeFinder Assay design Software of the Universal ProbeLibrary (Roche Life Science, Indianapolis, IN, USA) (Table 4).

Table 4. Sequences of the probes and primers used for the real-time quantitative PCR assays.

\begin{tabular}{ccc}
\hline Gene & Primer/Probe & Sequence \\
\hline \multirow{2}{*}{$c g M T$} & Forward primer & $5^{\prime}$-ACTGCCAGTGCAAATCCTG-3' \\
& Reverse primer & $5^{\prime}$-TCCTGAGGCACACTTACTGC-3' \\
& Probe & $5^{\prime}$-TGCTGCTC-3' \\
\hline \multirow{2}{*}{$\operatorname{sg}$-actin } & Forward primer & $5^{\prime}$-AGACACCAGGGTGTGATGGT-3 \\
& Reverse primer & $5^{\prime}$-GCTCTGAGCTTCATCACCA-3' \\
& Probe & $5^{\prime}$-GACCCAGA-3' \\
\hline
\end{tabular}

The reaction mixture contained the following: $2 \mu \mathrm{L}$ cDNA (1:10), $0.8 \mu \mathrm{L}$ of $10 \mu \mathrm{M}$ forward primer, $0.8 \mu \mathrm{L}$ of $10 \mu \mathrm{M}$ reverse primer, $0.2 \mu \mathrm{L}$ probe, $10 \mu \mathrm{L}$ of $2 \times$ ROX qPCR master mix (ThermoFisher Scientific) and nuclease free water (ThermoFisher Scientific), to make $20 \mu \mathrm{L}$. Thermal cycler conditions were as follows: incubation stage at $50{ }^{\circ} \mathrm{C}$ for $2 \mathrm{~min}$, initial denaturation at $95{ }^{\circ} \mathrm{C}$ for $10 \mathrm{~min}$, denaturation at $95^{\circ} \mathrm{C}$ for $15 \mathrm{~s}$, annealing and extension at $60^{\circ} \mathrm{C}$ for $1 \mathrm{~min}$ for 40 cycles. Negative controls were included in all the runs to confirm the absence of contamination. Additionally, to confirm that the amplification was only of synthesised cDNA and not of contaminating genomic DNA, after amplification, samples were analysed by electrophoresis on a $1 \%$ agarose gel. Since the two primers were designed to anneal to two different exons (Figure S5), amplification of genomic DNA would have led to larger PCR products, but no such larger PCR products were observed. All determinations are the result of three replicates.

Relative quantification of MT mRNA levels was carried out by standardising gene expression against the house-keeping gene $c g \beta$-actin, using the comparative $\Delta \Delta C_{\mathrm{t}}$-method. A sample from 
the Chimfunshi site that showed the lowest $c g M T$ expression levels was chosen as the control sample, and calculation of expression levels of $c g M T$ in each of the remaining 154 samples followed Equation (1):

$$
\left.\operatorname{cg} M T \text { fold change }=2^{-((\text {MT exposure }-\beta \text {-actin exposure })}-(\text { MT control }-\beta \text {-actin control })\right)
$$

\subsection{Heavy Metal Analysis in Fish Liver}

All laboratory equipment required for heavy metal analysis were pre-soaked in $2 \%(v / v) \mathrm{HCl}$ (ThermoFisher Scientific) overnight and rinsed twice with ultrapure water $(18 \mathrm{M} \Omega \cdot \mathrm{cm}$; Millipore Milli-Q, Watford, UK). All chemicals were analytical grade reagents, and Milli-Q water was used for the preparation of all solutions.

The liver samples were freeze-dried (VirTis, BenchTop K, SP Scientific, Gardiner, NY, USA) for $24 \mathrm{~h}$ and were acid digested following the Milestone DG-FO-17 digestion method for dried fish with some modifications. Approximately $0.5 \mathrm{~g}$ of each freeze dried liver sample was weighed, ground and homogenised and then transferred into a Teflon digestion vessel (Milestone Inc., Shelton, CT, USA). Metals were extracted using a closed microwave digestion system (Start D, Milestone) after addition of $7 \mathrm{~mL}$ of ultrapure $72 \%(v / v) \mathrm{HNO}_{3}$ (prepared in-house from reagent grade $\mathrm{HNO}_{3}$ by sub-boiling-point distillation) and $1 \mathrm{~mL}$ of $30 \%(v / v) \mathrm{H}_{2} \mathrm{O}_{2}$ (Primar-Trace analysis grade, ThermoFisher Scientific) to the digestion vessels. The digestion programme and temperature profile was as follows: step 1 (ramp time)- $1200 \mathrm{~W}$ at $180^{\circ} \mathrm{C}$ for $10 \mathrm{~min}$, step 2 (hold time)-1200 $\mathrm{W}$ at $180^{\circ} \mathrm{C}$ for $30 \mathrm{~min}$.

The digested samples were then diluted 31.25 fold with ultrapure water, keeping the contact time with glass to a minimum. The samples were analysed for total metal concentrations using the ${ }^{27} \mathrm{Al},{ }^{53} \mathrm{Cr}$, ${ }^{55} \mathrm{Mn},{ }^{56} \mathrm{Fe},{ }^{59} \mathrm{Co},{ }^{60} \mathrm{Ni},{ }^{63} \mathrm{Cu},{ }^{66} \mathrm{Zn},{ }^{75} \mathrm{As},{ }^{82} \mathrm{Se},{ }^{111} \mathrm{Cd},{ }^{202} \mathrm{Hg}$ and ${ }^{208} \mathrm{~Pb}$ isotopes and a 7500 series ICP-MS (Agilent Technologies, Stockport, UK) equipped with a cross flow nebuliser, a quartz spray chamber, and an Octopole Reaction System (ORS ${ }^{\circledR}$ ) cell. The instrument was operated in helium gas-mode to remove matrix interferences. A multi-element standard solution IV for ICP and a single mercury standard for ICP (Fluka Analytical, Buchs, Switzerland) were used to prepare seven multi-element standards $\left({ }^{27} \mathrm{Al},{ }^{75} \mathrm{As},{ }^{208} \mathrm{~Pb}-0.44\right.$ to $800 \mathrm{ppb},{ }^{53} \mathrm{Cr},{ }^{60} \mathrm{Ni},{ }^{63} \mathrm{Cu}-0.20$ to $400 \mathrm{ppb},{ }^{56} \mathrm{Fe},{ }^{66} \mathrm{Zn},{ }^{82} \mathrm{Se}-1.00$ to $2,000 \mathrm{ppb},{ }^{55} \mathrm{Mn},{ }^{59} \mathrm{Co},{ }^{111} \mathrm{Cd}-0.10$ to $200 \mathrm{ppb}$ and ${ }^{202} \mathrm{Hg}-0.02$ to $35.0 \mathrm{ppb}$ ) to provide suitable calibration curves. Only calibration curves with $r^{2}>0.999$ were accepted for concentration calculations. Erbium $\left({ }^{166} \mathrm{Er}\right)$ was used as an internal standard. For quality control, sample replicates were used to assess precision of the analyses, and reagent blanks and certified reference materials $\left(\mathrm{ERM}^{\circledR}-\mathrm{BB} 422\right.$, fish muscle European Commission; Sigma-Aldrich, Irvine, UK) were used to assess method accuracy. Hence, each ICP-MS run included triplicate blanks, standards, triplicate CRM and triplicate samples. The detection limits for heavy metal analysis (ppb) were: $\mathrm{Al}$ (1.203), $\mathrm{Cr}(0.05853), \mathrm{Mn}(0.02010)$, $\mathrm{Fe}$ (0.7638), Co (0.01884), Ni (0.06114), Cu (0.1284), Zn (0.2880), As (0.01216), Se (1.208), Cd (0.03024), $\mathrm{Hg}(0.008549)$ and $\mathrm{Pb}(0.006629)$.

\subsection{Statistical Analyses}

Descriptive statistics were calculated using Microsoft Excel ${ }^{\circledR}$ 2013. Further statistical analyses were performed using R (R Core Team, 2014, Vienna, Austria) after the data were normalised by $\log _{10}$ transformation. The mean values of concentrations of heavy metals and CgMT mRNA expression levels were then subjected to one-way analysis of variance (ANOVA) to test for spatial and seasonal differences $(p<0.05)$. Where significant differences were present, the mean values were separated using post-hoc Tukey's (honest significant difference) test. Pearson correlation analysis was performed to test for inter-metallic associations and associations between heavy metals and $c g M T$ gene expression levels $(p<0.05)$. Welch two sample $t$-test was used to test for sex differences in heavy metal accumulation and $c g M T$ gene expression levels $(p<0.05)$. 


\section{Conclusions}

This study established that C. gariepinus from the Kafue River experienced heavy metal contamination that varied depending on site and season. The potential of MT as a biomarker of heavy metal pollution in C. gariepinus from the Kafue River was demonstrated, especially for Cu. This information will be useful for environmental agencies and legislators to make rational decisions regarding further use of $c g M T$ as biomarker, heavy metal pollution of fish from the Kafue River, and the usage of these fish for human consumption.

In vitro biophysical analysis of the recombinantly expressed CgMT protein revealed typical "Zn-thionein" [91] character, very similar to mammalian MT2. The strong correlation of cgMT expression with $\mathrm{Cu}$ observed in the field study, and our inability to isolate Cu-bound CgMT are not as contradictory as it may seem, but give rise to the opportunity to consider the following observations and comments.

(i) In the ecotoxicological literature concerning MTs, there seems to be a widespread assumption that increased levels of MT protein provide protection against (acute) metal toxicity by sequestering the respective metal. Broadly speaking, metal toxicity can be mediated by adventitious binding of excess or toxic metal ions to biomolecules and/or by oxidative stress caused by redox active metal ions, primarily by generating reactive oxygen species, or by blocking reduced thiols. Accordingly, owing to their coordination and redox chemistry, MTs are in principle able to counteract both these modes of acute metal toxicity. It must be stressed though that there is no reason to claim that induction by a particular metal ion equates to in vivo binding or sequestration, unless this has been demonstrated experimentally, e.g., by appropriate metalloproteomics experiments on the native organism. Induction or even complex formation with a particular metal in vitro is insufficient to support such claims. Furthermore, Bourdineaud et al. have pointed out that MT induction may primarily serve to compensate for lysosomal degradation of existing MT protein, rather than necessarily leading to increased protein levels [49]. Together with the observation that toxic metal levels in cells can be easily higher than the total MT binding capacity, this argues against a simple sequestration role. Nevertheless, MTs can be one part of the machinery to deal with elevated or toxic metals. The fact that $\mathrm{Cu}-\mathrm{MT}$ association has been demonstrated very convincingly in fish liver cytosols even in control fish [99] suggests that at least some of the $\mathrm{Cu}$ enriched in C. gariepinus livers was bound to MT.

(ii) There is also the widespread assumption that heavy metal detoxification is part of the repertoire of biological functions of MTs. We note that there is some controversy regarding this, especially as far as vertebrates are concerned [35]. Even where toxic metal-MT interactions in vivo have been confirmed, an evolutionarily determined biological function cannot necessarily be inferred. Instead, it has been argued that in particular MT induction in response to cadmium exposure and in-vivo cadmium-binding are "properties" rather than functions of mammalian MTs [35]. Nevertheless, in organisms that are naturally exposed to these metals in soil or water, metal detoxification may well be an evolved function for MTs. The case for cadmium handling is particularly clear in some terrestrial invertebrates $[93,134,135]$. The situation in fish is unclear, but, given that fish inhabit environments where cadmium levels under normal circumstances are only two to three orders of magnitude lower than those of essential zinc, it is in principle possible that dealing with cadmium could be a true function of fish MTs, even though this was not apparent in our field study.

Supplementary Materials: Supplementary materials can be found at www.mdpi.com/1422-0067/18/7/1548/s1.

Acknowledgments: We thank the laboratory technical staff at the University of Warwick (especially Philip Aston) and the University of Zambia (Ladsluv Moonga and Joseph Ndebe). We are also grateful to Yona Essig (King's College London) for the assistance rendered in the laboratory analysis of samples. This study was supported by a grant from the International Foundation for Science (IFS) (No A/5212-1) and a scholarship to EM from the Commonwealth Scholarship Commission of the British Council (ZMCN-2013-352). AMA's visiting fellowship at the University of Warwick was supported by a grant from the European Union within the project "Enhancing Educational Potential of Nicolaus Copernicus University in the Disciplines of Mathematical and Natural Sciences" conducted under Sub-measure 4.1.1: Human Capital Operational Programme-Task 7 (Project No POKL.04.01.01-00-081/10)". We are grateful to the University of Warwick (Department of Chemistry), 
King's College London (Toxicogenomics Section) and University of Zambia for financial support and/or usage of facilities.

Author Contributions: Agnieszka Mierek-Adamska cloned the cgMT cDNA sequence, expressed and purified recombinant CgMT protein, and performed the biophysical analyses of recombinant CgMT protein. Ethel $\mathrm{M}^{\prime}$ kandawire conceived and designed the experiments. She also collected the samples and performed the experiments. She also contributed to the analysis of the data and drafted the paper. Kennedy Choongo conceived and designed the experiments and also contributed to sample collection. John Yabe conceived and designed the experiments and also contributed to sample collection. Maxwell Mwase conceived and designed the experiments and also contributed to sample collection. Ngonda Saasa analysed the data and contributed to the editing of the manuscript. Stephen R. Stürzenbaum enabled and advised on quantitative PCR experiments. Claudia A. Blindauer facilitated the project, advised on metal analysis and protein production and characterisation, and edited the final version of the manuscript. All authors contributed to manuscript writing.

Conflicts of Interest: The authors declare no conflict of interest.

\section{Abbreviations}

$\begin{array}{ll}\text { AEX } & \text { Anion exchange chromatography } \\ \text { BLAST } & \text { Basic local alignment search tool } \\ \text { BLASTN } & \text { Nucleotide BLAST } \\ \text { BLASTP } & \text { Protein BLAST } \\ \text { CDNA } & \text { Complementary DNA } \\ \text { CDS } & \text { Coding sequence } \\ \text { CgMT } & \text { Clarias gariepinus metallothionein protein } \\ \text { cgMT } & \text { Clarias gariepinus metallothionein coding sequence } \\ \text { EDTA } & 2,2^{\prime} \text {, }^{\prime \prime} \text {, }^{\prime \prime \prime} \text {-(Ethane-1,2-diyldinitrilo)tetraacetic acid } \\ \text { ESI-MS } & \text { Electrospray ionsation mass spectrometry } \\ \text { fMet } & \text { Formylated methionine } \\ \text { HSD } & \text { Honest significant difference } \\ \text { ICP-MS } & \text { Inductively-coupled plasma optical emission spectroscopy } \\ \text { ICP-MS } & \text { Inductively-coupled plasma mass spectrometry } \\ \text { LB } & \text { Lysogeny broth } \\ \text { mRNA } & \text { Messenger RNA } \\ \text { MT } & \text { Metallothionein } \\ \text { NCBI } & \text { National Center for Biotechnology Information } \\ \text { PCR } & \text { Polymerase chain reaction } \\ \text { PLI } & \text { Pollution load index } \\ \text { qPCR } & \text { Quantitative PCR } \\ \text { RI } & \text { Potential ecological risk index } \\ \text { RT-PCR } & \text { Reverse transcription PCR } \\ \text { SDS-PAGE } & \text { Sodium dodecyl sulphate polyacrylamide gel electrophoresis } \\ \text { SEC } & \text { Size-exclusion chromatography } \\ & \end{array}$

\section{References}

1. Zhou, Q.; Zhang, J.; Fu, J.; Shi, J.; Jiang, G. Biomonitoring: An appealing tool for assessment of metal pollution in the aquatic ecosystem. Anal. Chim. Acta 2008, 606, 135-150. [CrossRef] [PubMed]

2. McGeer, J.C.; Szebedinszky, C.; McDonald, D.G.; Wood, C.M. Effects of chronic sublethal exposure to waterborne $\mathrm{Cu}, \mathrm{Cd}$ or $\mathrm{Zn}$ in rainbow trout 2: Tissue specific metal accumulation. Aquat. Toxicol. 2000, 50, 245-256. [CrossRef]

3. Van der Oost, R.; Beyer, J.; Vermeulen, N.P.E. Fish bioaccumulation and biomarkers in environmental risk assessment: A review. Environ. Toxicol. Pharmacol. 2003, 13, 57-149. [CrossRef]

4. Bonner, F.W.; Bridges, J.W. Toxicological aspects of trace elements. In Trace Elements in Health; Rose, J., Ed.; Butterworths: London, UK, 1983; pp. 1-20.

5. Maret, W. The metals in the biological periodic system of the elements: Concepts and conjectures. Int. J. Mol. Sci. 2016, 17, 66. [CrossRef] [PubMed] 
6. Tchounwou, P.B.; Yedjou, C.G.; Patlolla, A.K.; Sutton, D.J. Heavy metal toxicity and the environment. EXS 2012, 101, 133-164. [PubMed]

7. Hursthouse, A.S. The relevance of speciation in the remediation of soils and sediments contaminated by metallic elements-An overview and examples from central Scotland, UK. J. Environ. Monit. 2001, 3, 49-60. [CrossRef] [PubMed]

8. Basha, P.S.; Rani, A.U. Cadmium-induced antioxidant defense mechanism in freshwater teleost Oreochromis mossambicus (Tilapia). Ecotox. Environ. Saf. 2003, 56, 218-221. [CrossRef]

9. Vilizzi, L.; Tarkan, A.S. Bioaccumulation of metals in common carp (Cyprinus carpio L.) from water bodies of Anatolia (Turkey): A review with implications for fisheries and human food consumption. Environ. Monit. Assess. 2016, 188, 243. [CrossRef] [PubMed]

10. Duruibe, J.O.; Ogwuegbu, M.O.C.; Egwurugwu, J.N. Heavy metal pollution and human biotoxic effects. Int. J. Phys. Sci. 2007, 2, 112-118.

11. Nogawa, K. Itai-itai disease and follow-up studies. In Cadmium in the Environment, Part II; Nriagu, J.O., Ed.; Wiley: New York, NY, USA, 1981; pp. 1-37.

12. Pettersson, U.T.; Ingri, J. The geochemistry of $\mathrm{Co}$ and $\mathrm{Cu}$ in the Kafue River as it drains the Copperbelt mining area, Zambia. Chem. Geol. 2001, 177, 399-414. [CrossRef]

13. Choongo, K.C.; Syakalima, M.S.; Mwase, M. Coefficient of condition in relation to copper levels in muscle of Serranochromis fish and sediment from the Kafue River, Zambia. Bull. Environ. Contam. Toxicol. 2005, 75, 645-651. [CrossRef] [PubMed]

14. Norrgren, L.; Pettersson, U.; Orn, S.; Bergqvist, P.A. Environmental monitoring of the Kafue River, located in the Copperbelt, Zambia. Arch. Environ. Contam. Toxicol. 2000, 38, 334-341. [CrossRef] [PubMed]

15. Sracek, O.; Kribek, B.; Mihaljevic, M.; Majer, V.; Veselovsky, F.; Vencelides, Z.; Nyambe, I. Mining-related contamination of surface water and sediments of the Kafue River drainage system in the Copperbelt district, Zambia: An example of a high neutralization capacity system. J. Geochem. Explor. 2012, 112, 174-188. [CrossRef]

16. Mbewe, G.; Mutondo, M.; Maseka, K.; Sichilongo, K. Assessment of heavy-metal pollution in sediments and tilapia fish species in Kafue River of Zambia. Arch. Environ. Contam. Toxicol. 2016, 71, 383-393. [CrossRef] [PubMed]

17. Mwase, M.; Viktor, T.; Norrgren, L. Effects on tropical fish of soil sediments from Kafue River, Zambia. Bull. Environ. Contam. Toxicol. 1998, 61, 96-101. [CrossRef] [PubMed]

18. Van Gestel, C.A.M.; van Brummelen, T.C. Incorporation of the biomarker concept in ecotoxicology calls for a redefinition of terms. Ecotoxicology 1996, 5, 217-225. [CrossRef] [PubMed]

19. Kägi, J.H.R.; Vallee, B.L. Metallothionein: A cadmium- and zinc-containing protein from equine renal cortex. J. Biol. Chem. 1960, 235, 3460-3465. [PubMed]

20. Olsson, P.-E. Toxicology of Aquatic Pollution: Physiological, Molecular and Cellular Approaches; Society for Experimental Biology Seminar Series; Taylor, E.W., Ed.; Cambridge University Press: Cambridge, UK, 1996; pp. 187-204.

21. Roesijadi, G. Metallothionein induction as a measure of response to metal exposure in aquatic animals. Environ. Health Perspect. 1994, 102, 91-95. [CrossRef] [PubMed]

22. Linde, A.R.; Sanchez-Galan, S.; Valles-Mota, P.; Garcia-Vazquez, E. Metallothionein as bioindicator of freshwater metal pollution: European eel and brown trout. Ecotoxicol. Environ. Saf. 2001, 49, 60-63. [CrossRef] [PubMed]

23. George, S.; Gubbins, M.; MacIntosh, A.; Reynolds, W.; Sabine, V.; Scott, A.; Thain, J. A comparison of pollutant biomarker responses with transcriptional responses in European flounders (Platicthys flesus) subjected to estuarine pollution. Mar. Environ. Res. 2004, 58, 571-575. [CrossRef] [PubMed]

24. Tom, M.; Chen, N.; Segev, M.; Herut, B.; Rinkevich, B. Quantifying fish metallothionein transcript by real time PCR for its utilization as an environmental biomarker. Mar. Pollut. Bull. 2004, 48, 705-710. [CrossRef] [PubMed]

25. Viarengo, A.; Burlando, B.; Dondero, F.; Marro, A.; Fabbri, R. Metallothionein as a tool in biomonitoring programmes. Biomarkers 1999, 4, 455-466.

26. Sarkar, A.; Ray, D.; Shrivastava, A.N.; Sarker, S. Molecular biomarkers: Their significance and application in marine pollution monitoring. Ecotoxicology 2006, 15, 333-340. [CrossRef] [PubMed] 
27. Hauser-Davis, R.A.; de Campos, R.C.; Ziolli, R.L. Fish metalloproteins as biomarkers of environmental contamination. In Reviews of Environmental Contamination and Toxicology; Whitacre, D.M., Ed.; Springer: New York, NY, USA, 2012; Volume 218, pp. 101-123.

28. Hemmadi, V. Metallothionein-A potential biomarker to assess the metal contamination in marine fishes. Int. J. Bioassays 2016, 5, 4961-4973. [CrossRef]

29. Blindauer, C.A.; Leszczyszyn, O.I. Metallothioneins: Unparalleled diversity in structures and functions for metal ion homeostasis and more. Nat. Prod. Rep. 2010, 27, 720-741. [CrossRef] [PubMed]

30. Kägi, J.H. Overview of metallothionein. In Methods in Enzymology; Elsevier: Amsterdam, The Netherlands, 1991; Volume 205, pp. 613-626.

31. Vašák, M. Advances in metallothionein structure and functions. J. Trace Elem. Med. Biol. 2005, 19, $13-17$. [CrossRef] [PubMed]

32. Capdevila, M.; Bofill, R.; Palacios, O.; Atrian, S. State-of-the-art of metallothioneins at the beginning of the 21st century. Coord. Chem. Rev. 2012, 256, 46-62. [CrossRef]

33. Sutherland, D.E.; Stillman, M.J. The "magic numbers" of metallothionein. Metallomics 2011, 3, $444-463$. [CrossRef] [PubMed]

34. Capdevila, M.; Atrian, S. Metallothionein protein evolution: A miniassay. J. Biol. Inorg. Chem. 2011, 16, 977-989. [CrossRef] [PubMed]

35. Blindauer, C.A. Metallothioneins. In Binding, Transport and Storage of Metal Ions in Biological Cells; Maret, W., Wedd, W., Eds.; Royal Society of Chemistry: London, UK, 2014; Volume 2, pp. 606-665.

36. Vergani, L. Metallothioneins in aquatic organisms: Fish, crustaceans, molluscs, and echinoderms. In Metal Ions in Life Sciences; Sigel, A., Sigel, H., Sigel, R.K.O., Eds.; Royal Society of Chemistry: Cambridge, UK, 2009; Volume 5, pp. 199-237.

37. Maret, W. Cellular zinc and redox states converge in the metallothionein/thionein pair. J. Nutr. 2003, 133, 1460S-1462S. [PubMed]

38. Buico, A.; Cassino, C.; Dondero, F.; Vergani, L.; Osella, D. Radical scavenging abilities of fish MT-A and mussel MT-10 metallothionein isoforms: An ESR study. J. Inorg. Biochem. 2008, 102, 921-927. [CrossRef] [PubMed]

39. Amiard, J.C.; Amiard-Triquet, C.; Barka, S.; Pellerin, J.; Rainbow, P.S. Metallothioneins in aquatic invertebrates: Their role in metal detoxification and their use as biomarkers. Aquat. Toxicol. 2006, 76, 160-202. [CrossRef] [PubMed]

40. Bracken, W.M.; Klaassen, C.D. Induction of metallothionein in rat primary hepatocyte cultures: Evidence for direct and indirect induction. J. Toxicol. Environ. Health 1987, 22, 163-174. [CrossRef] [PubMed]

41. Cherian, M.G.; Nordberg, M. Cellular adaptation in metal toxicology and metallothionein. Toxicology 1983, 28, 1-15. [CrossRef]

42. Thiele, D.J. Metal-regulated transcription in eukaryotes. Nucleic Acids Res. 1992, 20, 1183-1191. [CrossRef] [PubMed]

43. Olsson, P.E.; Kille, P. Functional comparison of the metal-regulated transcriptional control regions of metallothionein genes from cadmium-sensitive and tolerant fish species. Biochim. Biophys. Acta 1997, 1350, 325-334. [CrossRef]

44. Olsson, P.E.; Gerpe, M.; Kling, P. Functional and regulatory aspects of teleost metallothionein. In Metallothionein IV; Klaassen, C.D., Ed.; Birkhäuser Verlag AG: Basel, Switzerland, 1999; pp. 179-185.

45. Davis, S.R.; Cousins, R.J. Metallothionein expression in animals: A physiological perspective on function. J. Nutr. 2000, 130, 1085-1088. [PubMed]

46. He, P.F.; Xu, M.X.; Ren, H.W. Cloning and functional characterization of $5^{\prime}$-upstream region of metallothionein-I gene from crucian carp (Carassius cuvieri). Int. J. Biochem. Cell Biol. 2007, 39, 832-841. [CrossRef] [PubMed]

47. Bury, N.R.; Chung, M.J.; Sturm, A.; Walker, P.A.; Hogstrand, C. Cortisol stimulates the zinc signaling pathway and expression of metallothioneins and ZnT1 in rainbow trout gill epithelial cells. Am. J. Physiol. Regul. Integr. Comp. Physiol. 2008, 294, R623-R629. [CrossRef] [PubMed]

48. Mayer, G.D.; Leach, A.; Kling, P.; Olsson, P.E.; Hogstrand, C. Activation of the rainbow trout metallothionein-A promoter by silver and zinc. Comp. Biochem. Physiol. B 2003, 134, 181-188. [CrossRef]

49. Bourdineaud, J.P.; Baudrimont, M.; Gonzalez, P.; Moreau, J.L. Challenging the model for induction of metallothionein gene expression. Biochimie 2006, 88, 1787-1792. [CrossRef] [PubMed] 
50. Zafarullah, M.; Olsson, P.E.; Gedamu, L. Endogenous and heavy-metal-ion-induced metallothionein gene-expression in salmonid tissues and cell lines. Gene 1989, 83, 85-93. [CrossRef]

51. Van Campenhout, K.; Infante, H.G.; Hoff, P.T.; Moens, L.; Goemans, G.; Belpaire, C.; Adams, F.; Blust, R.; Bervoets, L. Cytosolic distribution of $\mathrm{Cd}, \mathrm{Cu}$ and $\mathrm{Zn}$, and metallothionein levels in relation to physiological changes in Gibel carp (Carassius auratus gibelio) from metal-impacted habitats. Ecotoxicol. Environ. Saf. 2010, 73, 296-305. [CrossRef] [PubMed]

52. Hayes, R.A.; Regondi, S.; Winter, M.J.; Butler, P.J.; Agradi, E.; Taylor, E.W.; Chipman, J.K. Cloning of a chub metallothionein cDNA and development of competitive RT-PCR of chub metallothionein mRNA as a potential biomarker of heavy metal exposure. Mar. Environ. Res. 2004, 58, 665-669. [CrossRef] [PubMed]

53. Petrlova, J.; Krizkova, S.; Zitka, O.; Hubalek, J.; Prusa, R.; Adam, V.; Wang, J.; Beklova, M.; Sures, B.; Kizek, R. Utilizing a chronopotentiometric sensor technique for metallothionein determination in fish tissues and their host parasites. Sens. Actuator B 2007, 127, 112-119. [CrossRef]

54. Aich, A.; Chattopadhyay, B.; Mukhopadhyay, S.K. Immunolocalization of metallothionein in hepatocytes of guppy fish (Poecilia reticulata) exposed to tannery effluent: A biomarker study. Chemosphere 2017, 169, 460-466. [CrossRef] [PubMed]

55. Langston, W.J.; Chesman, B.S.; Burt, G.R.; Pope, N.D.; McEvoy, J. Metallothionein in liver of eels Anguilla anguilla from the Thames estuary: An indicator of environmental quality? Mar. Environ. Res. 2002, 53, 263-293. [CrossRef]

56. Rodriguez-Cea, A.; Arias, A.R.L.; de la Campa, M.R.; Moreira, J.C.; Sanz-Medel, A. Metal speciation of metallothionein in white sea catfish, Netuma barba, and pearl cichlid, Geophagus brasiliensis, by orthogonal liquid chromatography coupled to ICP-MS detection. Talanta 2006, 69, 963-969. [CrossRef] [PubMed]

57. Van Campenhout, K.; Infante, H.G.; Goemans, G.; Belpaire, C.; Adams, F.; Blust, R.; Bervoets, L. A field survey of metal binding to metallothionein and other cytosolic ligands in liver of eels using an on-line isotope dilution method in combination with size exclusion (SE) high pressure liquid chromatography (HPLC) coupled to inductively coupled plasma time-of-flight mass spectrometry (ICP-TOFMS). Sci. Total Environ. 2008, 394, 379-389. [PubMed]

58. Vasconcelos, M.H.; Tam, S.C.; Hesketh, J.E.; Reid, M.; Beattie, J.H. Metal- and tissue-dependent relationship between metallothionein mRNA and protein. Toxicol. Appl. Pharmacol. 2002, 182, 91-97. [CrossRef] [PubMed]

59. Scudiero, R.; Carginale, V.; Riggio, M.; Capasso, C.; Capasso, A.; Kille, P.; diPrisco, G.; Parisi, E. Difference in hepatic metallothionein content in antarctic red-blooded and haemoglobinless fish: Undetectable metallothionein levels in haemoglobinless fish is accompanied by accumulation of untranslated metallothionein mRNA. Biochem. J. 1997, 322, 207-211. [CrossRef] [PubMed]

60. Ghedira, J.; Jebali, J.; Bouraoui, Z.; Banni, M.; Guerbej, H.; Boussetta, H. Metallothionein and metal levels in liver, gills and kidney of Sparus aurata exposed to sublethal doses of cadmium and copper. Fish Physiol. Biochem. 2010, 36, 101-107. [CrossRef] [PubMed]

61. Meyer, J.N.; Volz, D.C.; Freedman, J.H.; Di Giulio, R.T. Differential display of hepatic mRNA from killifish (Fundulus heteroclitus) inhabiting a superfund estuary. Aquat. Toxicol. 2005, 73, 327-341. [CrossRef] [PubMed]

62. Nakayama, S.M.M.; Ikenaka, Y.; Muzandu, K.; Choongo, K.; Oroszlany, B.; Teraoka, H.; Mizuno, N.; Ishizuka, M. Heavy metal accumulation in lake sediments, fish (Oreochromis niloticus and Serranochromis thumbergi), and crayfish (Cherax quadricarinatus) in Lake Itezhi-tezhi and Lake Kariba, Zambia. Arch. Environ. Contam. Toxicol. 2010, 59, 291-300. [CrossRef] [PubMed]

63. M'Kandawire, E.; Syakalima, M.; Muzandu, K.; Pandey, G.; Simuunza, M.; Nakayama, S.M.M.; Kawai, Y.K.; Ikenaka, Y.; Ishizuka, M. The nucleotide sequence of metallothioneins (MT) in liver of the Kafue lechwe (Kobus leche kafuensis) and their potential as biomarkers of heavy metal pollution of the Kafue River. Gene 2012, 506, 310-316. [CrossRef] [PubMed]

64. Coetzee, L.; du Preez, H.H.; van Vuren, J.H.J. Metal concentrations in Clarias gariepinus and Labeo umbratus from the Olifants and Klein Olifants river, Mpumalanga, South Africa: Zinc, copper, manganese, lead, chromium, nickel, aluminium and iron. Water $S A$ 2002, 28, 433-448. [CrossRef]

65. Skelton, P.H. A Complete Guide to the Freshwater Fishes of Southern Africa; Struik Publishers: Cape Town, South Africa, 2001.

66. Olojo, E.A.A.; Olurin, K.B.; Mbaka, G.; Oluwemimo, A.D. Histopathology of the gill and liver tissues of the African catfish Clarias gariepinus exposed to lead. Afr. J. Biotechnol. 2005, 4, 117-122. 
67. Jooste, A.; Marr, S.M.; Addo-Bediako, A.; Luus-Powell, W.J. Sharptooth catfish shows its metal: A case study of metal contamination at two impoundments in the Olifants River, Limpopo river system, South Africa. Ecotoxicol. Environ. Saf. 2015, 112, 96-104. [CrossRef] [PubMed]

68. Du Preez, G.; Wepener, V. Influence of mining pollution on metal bioaccumulation and biomarker responses in cave dwelling fish, Clarias gariepinus. Bull. Environ. Contam. Toxicol. 2016, 97, 18-23. [CrossRef] [PubMed]

69. Campana, O.; Sarasquete, C.; Blasco, J. Effect of lead on ala-d activity, metallothionein levels, and lipid peroxidation in blood, kidney, and liver of the toadfish Halobatrachus didactylus. Ecotoxicol. Environ. Saf. 2003, 55, 116-125. [CrossRef]

70. Chowdhury, M.J.; Pane, E.F.; Wood, C.M. Physiological effects of dietary cadmium acclimation and waterborne cadmium challenge in rainbow trout: Respiratory, ionoregulatory, and stress parameters. Comp. Biochem. Physiol. C 2004, 139, 163-173. [CrossRef] [PubMed]

71. Schlenk, D.; Zhang, Y.S.; Nix, J. Expression of hepatic metallothionein messenger-RNA in feral and caged fish species correlates with muscle mercury levels. Ecotoxicol. Environ. Saf. 1995, 31, 282-286. [CrossRef] [PubMed]

72. Olsvik, P.A.; Gundersen, P.; Andersen, R.A.; Zachariassen, K.E. Metal accumulation and metallothionein in two populations of brown trout, Salmo trutta, exposed to different natural water environments during a run-off episode. Aquat. Toxicol. 2000, 50, 301-316. [CrossRef]

73. Pathiratne, A.; Chandrasekera, L.; Pathiratne, K.A.S. Use of biomarkers in Nile tilapia (Oreochromis niloticus) to assess the impacts of pollution in Bolgoda lake, an urban water body in Sri Lanka. Environ. Monit. Assess. 2009, 156, 361-375. [CrossRef] [PubMed]

74. Oliveira, M.; Ahmad, I.; Maria, V.L.; Serafim, A.; Bebianno, M.J.; Pacheco, M.; Santos, M.A. Hepatic metallothionein concentrations in the golden grey mullet (Liza aurata)—Relationship with environmental metal concentrations in a metal-contaminated coastal system in Portugal. Mar. Environ. Res. 2010, 69, 227-233. [CrossRef] [PubMed]

75. Kille, P.; Stephens, P.E.; Kay, J. Elucidation of cDNA sequences for metallothioneins from rainbow-trout, stone loach and pike liver using the polymerase chain-reaction. Biochim. Biophys. Acta 1991, 1089, 407-410. [CrossRef]

76. Kambole, M.S. Managing the water quality of the Kafue River. Phys. Chem. Earth 2003, 28, 1105-1109. [CrossRef]

77. Sheppe, W.A. Effects of human activities on Zambia Kafue Flats ecosystems. Environ. Conserv. 1985, 12, 49-57. [CrossRef]

78. Choongo, E.H. Economic Aspects of the SADC Rural Industries Programme in Zambia; Zambian Alliance of Women: Lusaka, Zambia, 1994.

79. Soucek, D.J.; Cherry, D.S.; Currie, R.J.; Latimer, H.A.; Trent, G.C. Laboratory to field validation in an integrative assessment of an acid mine drainage-impacted watershed. Environ. Toxicol. Chem. 2000, 19, 1036-1043. [CrossRef]

80. Von der Heyden, C.J.; New, M.G. Sediment chemistry: A history of mine contaminant remediation and an assessment of processes and pollution potential. J. Geochem. Explor. 2004, 82, 35-57. [CrossRef]

81. M'kandawire, E.; Choongo, K.; Yabe, J.; Mwase, M.; Saasa, N.; Nakayama, S.M.M.; Bortey-Sam, N.; Blindauer, C.A. Sediment metal contamination in the Kafue River of Zambia and ecological risk assessment. Bull. Environ. Contam. Toxicol. 2017. [CrossRef] [PubMed]

82. Olafson, R.W.; Thompson, J.A. Isolation of heavy-metal binding-proteins from marine vertebrates. Mar. Biol. 1974, 28, 83-86. [CrossRef]

83. Quiniou, S.M.; Waldbieser, G.C.; Duke, M.V. A first generation BAC-based physical map of the channel catfish genome. BMC Genom. 2007, 8, 40. [CrossRef] [PubMed]

84. Lee, S.; Kim, C.; Kim, J.; Kim, W.K.; Shin, H.S.; Lim, E.S.; Lee, J.W.; Kim, S.; Kim, K.T.; Lee, S.K.; et al. Cloning metallothionein gene in Zacco platypus and its potential as an exposure biomarker against cadmium. Environ. Monit. Assess. 2015, 187, 7. [CrossRef] [PubMed]

85. Blindauer, C.A. Metallothioneins with unusual residues: Histidines as modulators of zinc affinity and reactivity. J. Inorg. Biochem. 2008, 102, 507-521. [CrossRef] [PubMed]

86. Vašák, M.; McClelland, C.E.; Hill, H.A.O.; Kägi, J.H.R. Role of lysine side-chains n metallothionein. Experientia 1985, 41, 30-34. [CrossRef] 
87. Scudiero, R.; Temussi, P.A.; Parisi, E. Fish and mammalian metallothioneins: A comparative study. Gene 2005, 345, 21-26. [CrossRef] [PubMed]

88. Capasso, C.; Carginale, V.; Crescenzi, O.; Di Maro, D.; Parisi, E.; Spadaccini, R.; Temussi, P.A. Solution structure of MT_nc, a novel metallothionein from the Antarctic fish Notothenia coriiceps. Structure 2003, 11, 435-443. [CrossRef]

89. Capasso, C.; Carginale, V.; Scudiero, R.; Crescenzi, O.; Spadaccini, R.; Temussi, P.A.; Parisi, E. Phylogenetic divergence of fish and mammalian metallothionein: Relationships with structural diversification and organismal temperature. J. Mol. Evol. 2003, 57, S250-S257. [CrossRef] [PubMed]

90. Kille, P.; Stephens, P.; Cryer, A.; Kay, J. The expression of a synthetic rainbow-trout metallothionein gene in Escherichia coli. Biochim. Biophys. Acta 1990, 1048, 178-186. [CrossRef]

91. Bofill, R.; Capdevila, M.; Atrian, S. Independent metal-binding features of recombinant metallothioneins convergently draw a step gradation between Zn- and Cu-thioneins. Metallomics 2009, 1, 229-234. [CrossRef] [PubMed]

92. Kowald, G.R.; Stürzenbaum, S.R.; Blindauer, C.A. Earthworm Lumbricus rubellus MT-2: Metal binding and protein folding of a true cadmium-MT. Int. J. Mol. Sci. 2016, 17, 16. [CrossRef] [PubMed]

93. Zeitoun-Ghandour, S.; Charnock, J.M.; Hodson, M.E.; Leszczyszyn, O.I.; Blindauer, C.A.; Sturzenbaum, S.R. The two caenorhabditis elegans metallothioneins (CeMT-1 and CeMT-2) discriminate between essential zinc and toxic cadmium. FEBS J. 2010, 277, 2531-2542. [CrossRef] [PubMed]

94. Kille, P.; Lees, W.E.; Darke, B.M.; Winge, D.R.; Dameron, C.T.; Stephens, P.E.; Kay, J. Sequestration of cadmium and copper by recombinant rainbow-trout and human metallothioneins and by chimeric (mermaid and fishman) proteins with interchanged domains. J. Biol. Chem. 1992, 267, 8042-8049. [PubMed]

95. Vergani, L.; Grattarola, M.; Borghi, C.; Dondero, F.; Viarengo, A. Fish and molluscan metallothioneins-A structural and functional comparison. FEBS J. 2005, 272, 6014-6023. [CrossRef] [PubMed]

96. Wingfield, P.T. N-terminal methionine processing. Curr. Protoc. Protein Sci. 2017, 88. [CrossRef]

97. Spector, S.; Flynn, J.M.; Tidor, B.; Baker, T.A.; Sauer, R.T. Expression of N-formylated proteins in Escherichia coli. Protein Expr. Purif. 2003, 32, 317-322. [CrossRef] [PubMed]

98. D’Auria, S.; Carginale, V.; Scudiero, R.; Crescenzi, O.; Di Maro, D.; Temussi, P.A.; Parisi, E.; Capasso, C. Structural characterization and thermal stability of Notothenia coriiceps metallothionein. Biochem. J. 2001, 354, 291-299. [CrossRef] [PubMed]

99. Infante, H.G.; Cuyckens, F.; Van Campenhout, K.; Blust, R.; Claeys, M.; Van Vaeck, L.; Adams, F.C. Characterization of metal complexes with metallothioneins in the liver of the carp Cyprinus carpio by reversed-phase, HPLC with ICP-MS and electrospray ionization (ESI)-MS. J. Anal. At. Spectrom. 2004, 19, 159-166. [CrossRef]

100. Palacios, O.; Atrian, S.; Capdevila, M. Zn- and Cu-thioneins: A functional classification for metallothioneins? J. Biol. Inorg. Chem. 2011, 16, 991-1009. [CrossRef] [PubMed]

101. Artells, E.; Palacios, O.; Capdevila, M.; Atrian, S. Mammalian MT1 and MT2 metallothioneins differ in their metal binding abilities. Metallomics 2013, 5, 1397-1410. [CrossRef] [PubMed]

102. Kelley, L.A.; Mezulis, S.; Yates, C.M.; Wass, M.N.; Sternberg, M.J.E. The Phyre2 web portal for protein modeling, prediction and analysis. Nat. Protoc. 2015, 10, 845-858. [CrossRef] [PubMed]

103. Braun, W.; Vašák, M.; Robbins, A.H.; Stout, C.D.; Wagner, G.; Kägi, J.H.R.; Wüthrich, K. Comparison of the NMR solution structure and the X-ray crystal-structure of rat metallothionein-2. Proc. Natl. Acad. Sci. USA 1992, 89, 10124-10128. [CrossRef] [PubMed]

104. Loska, K.; Wiechuła, D.; Korus, I. Metal contamination of farming soils affected by industry. Environ. Int. 2004, 30, 159-165. [CrossRef]

105. Gaspic, Z.K.; Zvonaric, T.; Vrgoc, N.; Odzak, N.; Baric, A. Cadmium and lead in selected tissues of two commercially important fish species from the Adriatic Sea. Water Res. 2002, 36, 5023-5028. [PubMed]

106. Rajkowska, M.; Protasowicki, M. Distribution of metals (Fe, Mn, Zn, Cu) in fish tissues in two lakes of different trophy in Northwestern Poland. Environ. Monit. Assess. 2013, 185, 3493-3502. [CrossRef] [PubMed]

107. Bird, D.J.; Rotchell, J.M.; Hesp, S.A.; Newton, L.C.; Hall, N.G.; Potter, I.C. To what extent are hepatic concentrations of heavy metals in Anguilla anguilla at a site in a contaminated estuary related to body size and age and reflected in the metallothionein concentrations? Environ. Pollut. 2008, 151, 641-651. [CrossRef] [PubMed] 
108. Tarras-Wahlberg, N.H.; Flachier, A.; Lane, S.N.; Sangfors, O. Environmental impacts and metal exposure of aquatic ecosystems in rivers contaminated by small scale gold mining: The Puyango River basin, southern Ecuador. Sci. Total Environ. 2001, 278, 239-261. [CrossRef]

109. Olsson, P.E.; Haux, C.; Förlin, L. Variations in hepatic metallothionein, zinc and copper levels during an annual reproductive cycle in rainbow trout, Salmo gairdneri. Fish Phys. Biochem. 1987, 3, 39-47. [CrossRef] [PubMed]

110. Yacoub, A.M.; Gad, N.S. Accumulation of some heavy metals and biochemical alterations in muscles of Oreochromis niloticus from the River Nile in Upper Egypt. Int. J. Environ. Sci. 2012, 3, 1-10.

111. Abdel-Satar, A.M. Environmental studies on the impact of the drains effluent upon the southern sector of Lake Manzalh, Egypt. Egypt. J. Aquat. Biol. Fish. 2001, 3, 17-30.

112. Khaled, A. Heavy metals concentrations in certain tissues of five commercially important fishes from El-Mex Bay, Alexandria, Egypt. Egypt. J. Aquat. Biol. Fish. 2004, 8, 51-64.

113. Ali, M.H.; Fishar, M.R. Accumulation of trace metals in some benthic invertebrate and fish species relevant to their concentration in water and sediment of lake Qarun, Egypt. Egypt. J. Aquat. Res. 2005, 31, $289-301$.

114. Nussey, G.; van Vuren, J.H.J.; du Preez, H.H. Bioaccumulation of chromium, manganese, nickel and lead in the tissues of the moggel, Labeo umbratus (cyprinidae), from Witbank dam, Mpumalanga. Water SA 2000, 26, 269-284.

115. Bremner, I. Interactions between metallothionein and trace elements. Prog. Food Nutr. Sci. 1987, 11, 1-37. [PubMed]

116. Chan, K.M.; Ku, L.L.; Chan, P.C.Y.; Cheuk, W.K. Metallothionein gene expression in zebrafish embryo-larvae and ZFL cell-line exposed to heavy metal ions. Mar. Environ. Res. 2006, 62, S83-S87. [CrossRef] [PubMed]

117. Liu, J.; Liu, Y.; Goyer, R.A.; Achanzar, W.; Waalkes, M.P. Metallothionein-I/II null mice are more sensitive than wild-type mice to the hepatotoxic and nephrotoxic effects of chronic oral or injected inorganic arsenicals. Toxicol. Sci. 2000, 55, 460-467. [CrossRef] [PubMed]

118. Hauser-Davis, R.A.; Silva, J.A.; Rocha, R.C.; Saint'Pierre, T.; Ziolli, R.L.; Arruda, M.A. Acute selenium selenite exposure effects on oxidative stress biomarkers and essential metals and trace-elements in the model organism zebrafish (Danio rerio). J. Trace Elem. Med. Biol. 2016, 33, 68-72. [CrossRef] [PubMed]

119. Klaassen, C.D.; Liu, J.; Diwan, B.A. Metallothionein protection of cadmium toxicity. Toxicol. Appl. Pharmacol. 2009, 238, 215-220. [CrossRef] [PubMed]

120. Hogstrand, C.; Lithner, G.; Haux, C. The importance of metallothionein for the accumulation of copper, zinc and cadmium in environmentally exposed perch, Perca fluviatilis. Pharmacol. Toxicol. 1991, 68, 492-501. [CrossRef] [PubMed]

121. Filipovic, V.; Raspor, B. Metallothionein and metal levels in cytosol of liver, kidney and brain in relation to growth parameters of Mullus surmuletus and Liza aurata from the eastern Adriatic sea. Water Res. 2003, 37, 3253-3262. [CrossRef]

122. Bervoets, L.; Knapen, D.; De Jonge, M.; Van Campenhout, K.; Blust, R. Differential hepatic metal and metallothionein levels in three feral fish species along a metal pollution gradient. PLoS ONE 2013, 8, e60805. [CrossRef] [PubMed]

123. Steinbrenner, H.; Speckmann, B.; Klotz, L.O. Selenoproteins: Antioxidant selenoenzymes and beyond. Arch. Biochem. Biophys. 2016, 595, 113-119. [CrossRef] [PubMed]

124. Navarro, A.; Quiros, L.; Casado, M.; Faria, M.; Carrasco, L.; Benejam, L.; Benito, J.; Diez, S.; Raldua, D.; Barata, C.; et al. Physiological responses to mercury in feral carp populations inhabiting the low Ebro river (NE Spain), a historically contaminated site. Aquat. Toxicol. 2009, 93, 150-157. [CrossRef] [PubMed]

125. Monteiro, D.A.; Rantin, F.T.; Kalinin, A.L. Inorganic mercury exposure: Toxicological effects, oxidative stress biomarkers and bioaccumulation in the tropical freshwater fish matrinx, Brycon amazonicus (Spix and Agassiz, 1829). Ecotoxicology 2010, 19, 105-123. [CrossRef] [PubMed]

126. Sinaie, M.; Bastami, K.D.; Ghorbanpour, M.; Najafzadeh, H.; Shekari, M.; Haghparast, S. Metallothionein biosynthesis as a detoxification mechanism in mercury exposure in fish, spotted scat (Scatophagus argus). Fish Physiol. Biochem. 2010, 36, 1235-1242. [CrossRef] [PubMed]

127. Banni, M.; Jebali, J.; Guerbej, H.; Dondero, F.; Boussetta, H.; Viarengo, A. Mixture toxicity assessment of nickel and chlorpyrifos in the sea bass Dicentrarchus labrax. Arch. Environ. Contam. Toxicol. 2011, 60, 124-131. [CrossRef] [PubMed] 
128. Velma, V.; Tchounwou, P.B. Hexavalent chromium-induced multiple biomarker responses in liver and kidney of goldfish, Carassius auratus. Environ. Toxicol. 2011, 26, 649-656. [CrossRef] [PubMed]

129. Ceyhun, S.B.; Aksakal, E.; Ekinci, D.; Erdogan, O.; Beydemir, S. Influence of cobalt and zinc exposure on mRNA expression profiles of metallothionein and cytocrome P450 in rainbow trout. Biol. Trace Elem. Res. 2011, 144, 781-789. [CrossRef] [PubMed]

130. Paul, J.F. Developing and applying an index of environmental integrity for the US Mid-Atlantic region. J. Environ. Manag. 2003, 67, 175-185. [CrossRef]

131. Tomlinson, D.L.; Wilson, J.G.; Harris, C.R.; Jeffrey, D.W. Problems in the assessment of heavy-metal levels in estuaries and the formation of a pollution index. Helgol. Meeresunters. 1980, 33, 566-575. [CrossRef]

132. Hakanson, L. An ecological risk index for aqwuatoc pollution control. A sedimentological approach. Water Res. 1980, 14, 975-1001. [CrossRef]

133. Ellman, G.L. Tissue sulfhydryl groups. Arch. Biochem. Biophys. 1959, 82, 70-77. [CrossRef]

134. Dallinger, R.; Berger, B.; Gruber, C.; Hunziker, P.; Stürzenbaum, S. Metallothioneins in terrestrial invertebrates: Structural aspects, biological significance and implications for their use as biomarkers. Cell. Mol. Biol. 2000, 46, 331-346. [PubMed]

135. Höckner, M.; Dallinger, R.; Stürzenbaum, S.R. Nematode and snail metallothioneins. J. Biol. Inorg. Chem. 2011, 16, 1057-1065. [CrossRef] [PubMed]

(C) 2017 by the authors. Licensee MDPI, Basel, Switzerland. This article is an open access article distributed under the terms and conditions of the Creative Commons Attribution (CC BY) license (http://creativecommons.org/licenses/by/4.0/). 